\title{
Intermolecular 1,3-Dipolar Cycloadditions of Münchnones with Acetylenic Dipolarophiles: Sorting out the Regioselectivity
}

\author{
Brian P. Coppola* ${ }^{\star}$, Mark C. Noe ${ }^{\dagger}$, David J. Schwartz ${ }^{\dagger}$, Robert L. II Abdon $\dagger$, \\ and Barry $M$. Trost ${ }^{*}, 8$

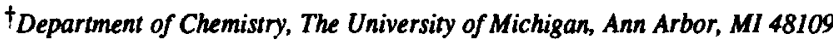 \\ \$Department of Chemistry, Stanford University, Stanford, CA 94305 \\ Department of Chemistry, The University of Wisconsin-Madison, Madison, WI 53706
}

\begin{abstract}
A series of 1,3-dipolar cyclaadditions of mulnchnones with acetylenic dipolanophiles was studied, wherein factors related to regioselectivity were investigated. The results from munchnones with electronically divergent thioaryl substituents compared with others bearing alkyl substituents suggest that an unsymmetrical transition state structure, rather than FMO perturbation, plays a significant role in regioselection. If eclipsing interactions preclude a bighly unsymmetrical transition state, however, then minimizing steric interactions becomes important. A pair of complementarily substituted múnchnones, differing only in the position of isotopic labels, establishes an inherently symmetrical electronic nature of the mesoionic heterocycle.
\end{abstract}

\section{INTRODUCTION}

Some 1,3-dipolar cycloaddition reactions have limited synthetic utility because of their unpredictable and/or low regioselectivities. The many productive applications of this cycloaddition chemistry continue to spur interest in (a), defining the contributing factors that influence the distribution of products ${ }^{1}$ and (b), creating regiochemical and stereochemical control elements that can increase the predictability and selectivity of the reactions. ${ }^{2}$ Historically, outside of intermolecular complexation (such as hydrogen bonding), or intramolecular tethering of the reacting partners, the regioselectivities observed in 1,3-dipolar cycloaddition reactions have been rationalized by FMO interactions. ${ }^{3}$ In the past few years, the role of non-covalent interactions has been included in these analyses. Huisgen has summarized these effects as they pertain to some experimental observations. ${ }^{4}$ Sustmann has explicitly incorporated a partitioned contribution from covalent and non-covalent interactions into a computational model. 5 Improving models for analyzing transition state structures, especially in conjunction with experimental observations, may create ways to evaluate the balance of many contributing factors for a given cycloaddition reaction. This is important for reactions where 
asynchronous bond formations and high dipolar character conflict with the usual assumptions about transition state structure. 6

The 1,3-dipolar cycloaddition reactions of mesoionic compounds have eluded an even loosely unified theory to account for observed regioselectivities. ${ }^{7}$ As part of an investigation into methods that may be used to control the cycloaddition regioselectivity of these compounds, we have re-examined factors to which the observed regioselectivities have been attributed. We have prepared a set of molecules where we have attempted to isolate the electronic distributing (FMO) and non-covalent effects of substituents. We have found evidence that the degree of symmetry in the transition state structure may be highly related to the steric interactions between dipole/dipolarophile substituents, and plays a more significant role in regioselection than FMO effects. The results from a set of compounds with isotopically labeled substituents provides the most direct evidence to date that there is no inherent electronic bias contributed by the mesoionic heterocycle.

Because of the ready availability and variety of substituted amino acid precursors, we selected the mesoionic 1,3-oxazolium-5-olates (münchnones) 2 (eq. 1) to further study the factors influencing the regioselectivity of cycloaddition reactions with acetylenic dipolarophiles. Generally, münchnones are not isolated, but are generated in situ by the cyclodehydration of secondary $\mathrm{N}$-acylamino acids 1 in the presence of a dipolarophile. The cycloaddition reactions with acetylenic dipolarophiles efficiently give pyrroles 3 and 4 after a decarboxylative cycloreversion, which also occurs under the reaction conditions.

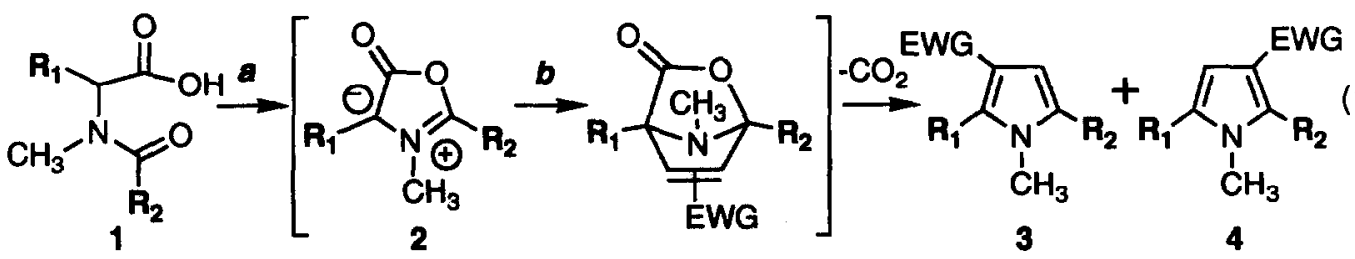

\section{a) $\left.\mathrm{A}_{2} \mathrm{O} ; b\right)$ EWG (EWG = electron-withdrawing group)}

Huisgen, ${ }^{8}$ Padwa, ${ }^{9}$ and others ${ }^{10}$ have studied münchnone cycloaddition reactions in some detail. Mechanistic experiments performed with münchnones imply that the observed product distributions are the result of kinetic control. 11 Many of these investigations have concluded that the substituents on the mesoionic heterocycle are the dominant influence on the FMO electronic distribution, and therefore the regioselectivity. On the other hand, results consistent with the apparent electronic effect of the heterocycle itself are also known. $8 \mathrm{c}, 12$ The reaction of an unsymmetrically substituted monocyclic münchnone with methyl propiolate is the archetypical example of a cycloaddition that gives rise to a mixture of pyrrole regioisomers. In the case where one of the substituents is a hydrogen atom, there is a very consistent trend to produce the 3pyrrolecarboxylate isomer (eq. 2) as the major product. ${ }^{13}$ The product distribution of regioisomers is<smiles>[R]C(=O)N(C)C(C(=O)O)C(=O)N(C)C(=O)C(=O)OC</smiles> 
generally in about a 3-to-4:1 ratio favoring this isomer, regardless of the original position of the hydrogen atom substituent ( $\mathbf{R}_{1}$ or $\mathbf{R}_{2}$ in 1 , see eq. 2 ). There are a few examples that are noteworthy exceptions to this generalization. First, the hydrogen/trifluoromethyl-substituted münchnone gives the opposite sense of regioselectivity (eq. 3). 8 Second, polycyclic münchnones derived, for example, from $\mathrm{N}$-acylproline and $\mathrm{N}$ acyl(homoproline) give the bicyclic products shown in eq. 4 with very high regioselectivity. 14 Even here, however, a substituent with a strong charge stabilizing effect counteracts this generalization. 15 There are many examples of 1,3-dipolar cycloadditions that are consistent with the formation of the more crowded adduct as the major isomer, as in eq. 2: the addition of some non-stabilized azomethine ylids 16 to methyl propiolate, the analogous carbonyl ylids, 17 isomünchnones, 18 and azomethine imines. 19

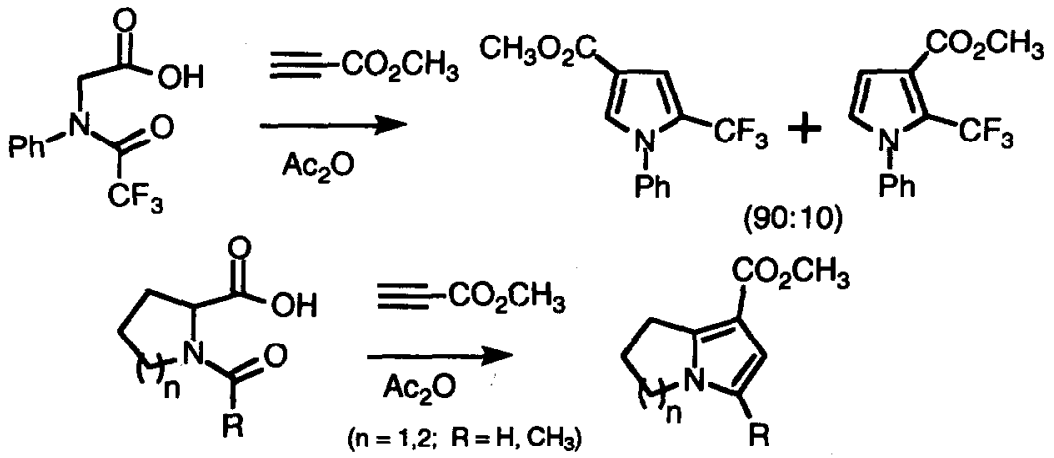

\section{RESULTS AND DISCUSSION}

Electronic Effect of Munchnone Substituents. Arylthio groups have been used in conjunction with alkoxy and acyloxy groups as regiocontrol elements for Diels-Alder cycloaddition reactions. ${ }^{20 a, b}$ More recently, they have been used in a similar fashion in palladium catalyzed cycloadditions involving substituted trimethylenemethane units. $20 \mathrm{c}$ Testing such substituents seemed especially attractive in the 1,3-dipole question, where FMO electronic effects had generally received strong attribution. As reference compounds, we

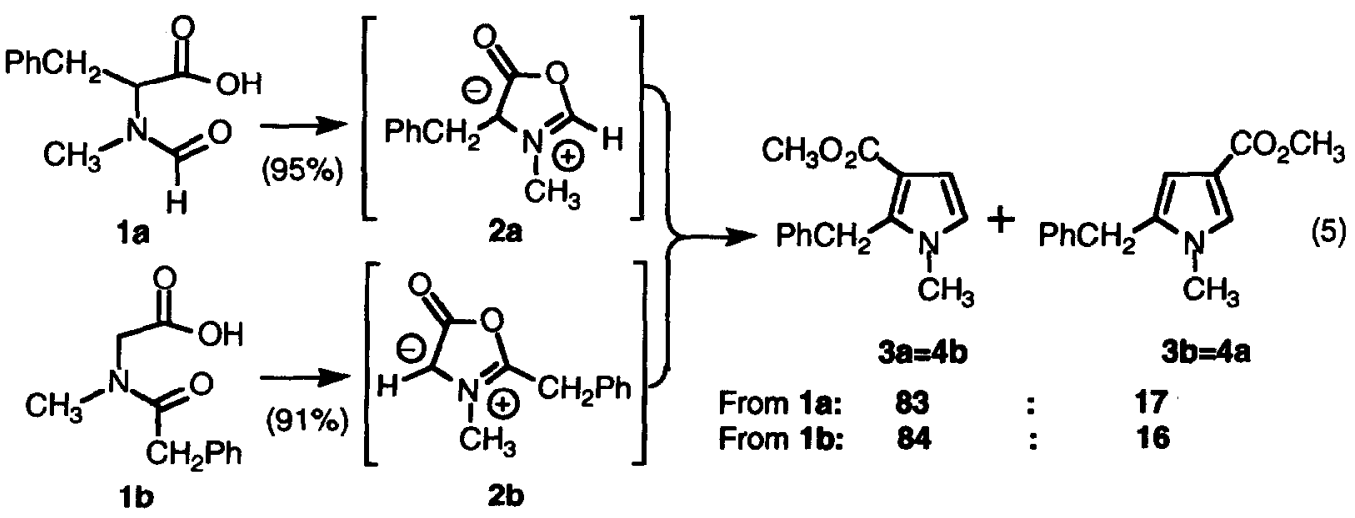


prepared the two $\mathrm{N}$-acylamino acids 1a-b21 (eq. 5) that yield a pair of regioisomeric münchnones $2 \mathrm{a}-\mathrm{b}$ under the cyclodehydration reaction conditions. The same regioisomeric distributions of pyrroles, $(3 a=4 b):(3 b=4 a)$, were observed. This result is consistent with those observed for the other reported cases of regioisomeric münchnone pairs (see Table VI).

The series of $\mathrm{N}$-acyl- $\alpha$-(arylthio)amino acids $1 \mathrm{c}-\mathrm{f}$ was prepared by the amidoalkylation 22 reaction of arylthiols with $\mathrm{N}$-formyl- $\mathrm{N}$-methyl- $\alpha$-hydroxyglycine. The ratios of regioisomeric pyrroles resulting from the cycloaddition of the derived münchnone with methyl propiolate were determined. 23 These results are summarized in Table I. As noted earlier, the major regioisomer in each case is the 2-substituted pyrrole-3carboxylate. There are two interesting features in this series of experiments that contrast with the typical behavior observed in Diels-Alder reactions. ${ }^{24}$ First, the electronically divergent series of arylthio substituents in 1c-f, which demonstrated successful regiocontrol as part of Diels-Alder dienes, do not dramatically affect the regioselectivities observed in the münchnone cycloadditions. Second, the regioselectivities of the arylthiosubstituted münchnone reactions, taken together, are the same as both of the benzyl-substituted münchnones derived from $1 \mathrm{a}$ and $\mathbf{1 b}$.

TABLE 1. Cycloaddition Reactions of Arylthio-substituted Munchnones

1c: $\mathrm{Ar}=\mathrm{p}-\mathrm{CH}_{3} \mathrm{OPh}-$
1d: $\mathrm{Ar}=\mathrm{Ph}-$

The MNDO-derived coefficients and charges do not help to clarify this picture. A HOMOdipole control assumption is commonly used for cycloaddition reactions with electron-poor dipolarophiles. 25 The reactivity profile of münchnones with various dipolarophiles is consistent with Sustmann's Type I classification $25 \mathrm{c}$ (HOMO dipole- $_{\text {LUMO }}$ dipolarophile control). The results from MNDO calculations ${ }^{26}$ on the mlinchnones $2 \mathrm{a}-\mathrm{f}$ imply that the regiochemistry should be dominated by the higher coefficient $(c)$ and charge density $(q)$ on the carbonyl substituted C-4 terminus. This is only consistent with the results from example $\mathbf{2 b}$, where the nonhydrogen substituent is at C-2. A number of different interaction energy terms have been used to qualitatively correlate regioselectivity differences. ${ }^{3 b}$ The $\Delta \mathrm{E}_{\mathrm{ct}}$ (charge transfer interaction) and $\Delta \mathrm{E}_{\mathrm{el}}$ (electrostatic interaction) have both been used with MINDO-derived data for münchnone systems. ${ }^{9}$ The Type II behavior of two energetically comparable FMO interactions has also been suggested, 27 particularly in evaluating the $\Delta \mathrm{E}_{\mathrm{ct}}$ ratio as an index for regiochemical prediction. The MNDO-derived FMO data and the $\Delta \mathrm{E}_{\mathrm{ct}}$ ratios for compounds 1a-f are given in Tables II and III, respectively. The similarity of the $\Delta \mathrm{E}_{\mathrm{ct}}$ ratios is comforting from the perspective that the observed regioselectivities were roughly the same for all six cases. However,the $\Delta \mathrm{E}_{\mathrm{ct}}$ values are all just slightly greater than unity, which predicts only a small regioselectivity in favor of the 
same orientation predicted by the HOMO dipole control assumption, which is not observed except for $\mathbf{2 b}$. Values of $\mathbf{1 . 2 5}$ and 2.37 were calculated in the cases of a münchnone and a sydnone, respectively, when modeling reactions that gave 75:25 regioisomeric ratios. ${ }^{9}$ The relatively narrow HOMO/LUMO gaps calculated for all six of these dipoles lie within the HOMO/LUMO gap calculated for the dipolarophile. Both of the FMO interactions taken together (Type II assumption, as used in the $\Delta \mathrm{E}_{\mathrm{ct}}$ calculation) must result in no significant regioselection based on substituent perturbation. The previously cited trifluoromethyl/hydrogen-substituted münchnone (eq. 3) stands as the single example that contradicts this generalization. In this case, the electronic perturbation due to the $\mathrm{C}-2$ trifluoromethyl substituent might be strong enough to close one of the FMO gaps into dominance.

TABLE II. MNDO Values for Munchnones 2a-f

\begin{tabular}{|c|c|c|c|c|c|c|c|c|c|}
\hline $\mathbf{R}_{1}$ & $\mathbf{R}_{\mathbf{2}}$ & НОМО & $c_{2}$ & $c_{4}$ & $q_{2}$ & $q_{4}$ & LUMO & $c_{2}$ & $c_{4}$ \\
\hline $\begin{array}{l}\text { 2a: } \mathrm{PhCH}_{2-}^{-} \\
\text {2b: } \mathrm{H}- \\
\text { 2c: } \\
\text { 2d: } \mathrm{Ch} \\
\text { 2d } \mathrm{OPhS}- \\
\text { 2e: } \mathrm{Ph}-\mathrm{CF}_{3} \mathrm{PhS}- \\
\text { 2f: } \mathrm{p}-\mathrm{NO}_{2} \mathrm{PhS}-\end{array}$ & $\begin{array}{l}-\mathrm{H} \\
-\mathrm{CH}_{2} \mathrm{Ph} \\
-\mathrm{H} \\
-\mathrm{H} \\
-\mathrm{H} \\
-\mathrm{H}\end{array}$ & $\begin{array}{l}-8.01 \mathrm{eV} \\
-7.89 \mathrm{eV} \\
-8.42 \mathrm{eV} \\
-8.37 \mathrm{eV} \\
-8.58 \mathrm{eV} \\
-8.79 \mathrm{eV}\end{array}$ & $\begin{array}{l}0.48 \\
0.44 \\
0.40 \\
0.41 \\
0.39 \\
0.41\end{array}$ & $\begin{array}{l}-0.71 \\
-0.64 \\
-0.68 \\
-0.69 \\
-0.69 \\
-0.73\end{array}$ & $\begin{array}{l}0.11 \\
0.12 \\
0.17 \\
0.17 \\
0.18 \\
0.19\end{array}$ & $\begin{array}{l}-0.30 \\
-0.31 \\
-0.48 \\
-0.48 \\
-0.49 \\
-0.50\end{array}$ & $\begin{array}{l}-0.38 \mathrm{eV} \\
-0.33 \mathrm{eV} \\
-0.68 \mathrm{eV} \\
-0.64 \mathrm{eV} \\
-0.82 \mathrm{eV} \\
-0.99 \mathrm{eV}\end{array}$ & $\begin{array}{l}0.68 \\
0.54 \\
0.71 \\
0.71 \\
0.69 \\
0.72\end{array}$ & $\begin{array}{l}0.38 \\
0.33 \\
0.34 \\
0.34 \\
0.32 \\
0.32\end{array}$ \\
\hline
\end{tabular}

TABLE III. $\Delta \mathrm{E}_{\mathrm{ct}}$ Ratios for 2a-f Cycloadditions with Methyl Propiolate

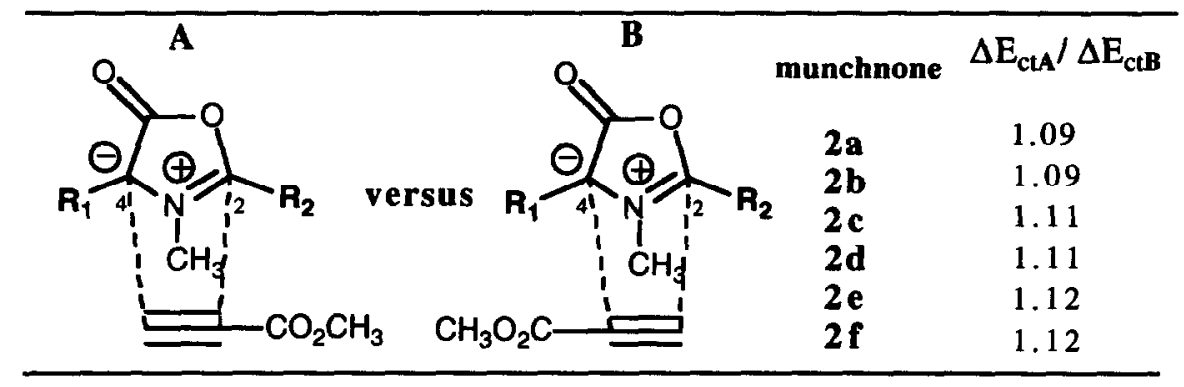

The results from the regioisomeric pairs of münchnones (such as $2 \mathbf{a}$ and $\mathbf{2 b}$ ) are the most convincing evidence favoring substituent control in the regioselectivity of the cycloaddition reactions. The nature of the substituent effect is an open question, however. Furthermore, there are cases where analogous pairs of münchnones give products which reflect a complete insensitivity to the placement of exocychic substituents. $8 \mathrm{c}, 12$ Given the general lack of sensitivity to electronic perturbation observed with the arylthio substituents, both within the series and relative to the benzyl-substituted compounds, it is tempting to view these münchnones as a class of sterically similar compounds. The contrathermodynamic selection of the more 
crowded pyrrole isomer might allow an insight into the transition state structure of the kinetically controlled cycloaddition reactions. We propose that an unsymmetrical transition state is favored in the case where one of the münchnone's dipolar termini bears a hydrogen atom. This transition state has advanced bond formation between the hydrogen-substituted terminus of the dipole and the sterically less demanding $\beta$-carbon of methyl propiolate, which represents a high Michael-like character in the initial bond-forming process (Fig. 1).28 Such a criterion may be especially significant for acetylenic dipolarophiles because the münchnone's substituents are expected to eclipse those of the dipolarophile during the cycloaddition reaction.

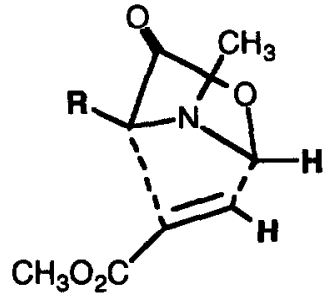

Figure 1. Proposed Unsymmetrical Transition State Structure for R/H-Substituted Münchnone Cycloaddition

The Nature of the Mesoionic Heterocycle. The inherent bias of the mesoionic heterocycle has never been unequivocably established for any substituent. The inference from regioisomeric münchnone pairs such as $\mathbf{2 a}$ and $\mathbf{2 b}$ is that there is an insignificant regiochemical contribution due to the unsymmetrical nature of the oxazolium ring, and that selectivity is dominated by a substituent effect. Padwa 16 has reported the single example which is a direct comparison between an identically substituted münchnone (a stabilized azomethine ylid) with respect to its non-stabilized azomethine ylid counterpart. In this case, the regioselectivities observed with methyl propiolate were the same, implying no additional effect due to the mesoionic ring. Unfortunately, there are a limited number of examples of münchnone cycloadditions with unsymmetrical dipolarophiles where the electronic effects of the different substituents $\mathbf{R}_{1}$ and $\mathbf{R}_{2}$ (in 2) are predicted to be equal. In the handful of cases where both $\mathbf{R}_{1}$ and $\mathbf{R}_{2}$ are alkyl groups, regioselectivities ranging from high to none have been reported. 29 In the case of identical substituents $\mathbf{R}_{\mathbf{1}}=\mathbf{R}_{\mathbf{2}}$, the regiochemical information with respect to the original heterocycle is lost since decarboxylation from both of the non-isolable 30 bicyclic intermediates gives the same pyrrole isomer $(3=4)$.

We have prepared a pair of regioisomeric dipoles that differ only by the position of isotopic labels in order to establish the inherent electronic bias of the münchnone heterocycle. The synthesis of two ${ }^{13} \mathrm{C}$-labeled $\mathrm{N}$-acylamino acid ${ }^{31}$ münchnone precursors $1 \mathrm{~g}$ and $1 \mathrm{~h}$ is outlined in the Scheme. ${ }^{32}$ Under the standard cycloaddition conditions, these precursors generate a pair of münchnones differentiated only by the position of the isotopically enriched methyl group ( $2 \mathrm{~g}: \mathbf{R}_{1}={ }^{12} \mathrm{CH}_{3}, \mathbf{R}_{2}={ }^{13} \mathrm{CH}_{3}$ and vice versa, $2 \mathrm{~h}$ ).

Methyl propiolate was once again used as the dipolarophile in the cycloadditions reactions. The $\mathbf{R}_{\mathbf{1}}=$ $\mathbf{R}_{2}={ }^{12} \mathrm{CH}_{3}$ pyrrole, $3 \mathrm{i}=4 \mathrm{i}$, derived from $\mathrm{N}$-acetyl- $\mathrm{N}$-methylalanine, 33 served as the spectroscopic reference compound. In both cases, isomeric ratios could be easily determined by ${ }^{1} \mathrm{H}$ - and ${ }^{13} \mathrm{C}$-NMR analyses of the crude reaction mixtures. 34 The results of the cycloaddition experiments are summarized in Table IV. The slight regioselectivity observed from both of the ${ }^{13} \mathrm{C}$-labeled isomers suggests that only a small inherent bias. 
<smiles>CC(NN(C)C(=O)c1ccccc1)C(C)C(=O)O</smiles><smiles>CNC(C)C(=O)O</smiles><smiles>CC(=O)N(C)C(C)C(=O)O</smiles>

$\mathbf{1 h}$

a) 1) $\mathrm{PhCH} 2 \mathrm{OH} / \mathrm{SOCl} / 100^{\circ} \mathrm{C} / 5 \mathrm{hr}$; 2) Et $3 \mathrm{~N} / \mathrm{EtOAC}$; b) 1) ${ }^{13} \mathrm{CH}_{3} \mathrm{CO}_{2} \mathrm{H} / \mathrm{DCC} / \mathrm{CH}_{2} \mathrm{Cl}_{2}$, 2) $\mathrm{H}_{2} / 5 \%$ Pd-C/ ACOH / EtOAC;

c) 1) $\mathrm{PhCH}_{2} \mathrm{OCOCl}$, 2) $9 \mathrm{CH}_{3} \mathrm{I} / \mathrm{NaH} / \mathrm{THF}$, 3) $\mathrm{H}_{2} / 10 \% \mathrm{Pd}-\mathrm{Cl}^{\prime} \mathrm{CH}_{3} \mathrm{OH} / \mathrm{ACOH}$; d) $\mathrm{AC} 2 \mathrm{O} / \mathrm{NaOH} / \mathrm{H}_{2} \mathrm{O}$

\section{Scheme. Synthesis of Isotopically Labelled Amido Acids}

at best, can be attributed to the mesoionic heterocycle. This observed bias is consistent with all of the previously calculated $\Delta \mathrm{E}_{\mathrm{ct}}$ ratios for $\mathbf{2 a - f}$, as well as the $\mathrm{HOMO}_{\text {dipole-control assumption, in which the }}$ carbonyl-substituted terminus of the münchnone is predicted to be more electron-rich, thereby showing a regioselectivity in favor of the electron-deficient $B$-carbon of methyl propiolate. The $\Delta E_{c t}$ ratio calculated for $2 i$ (the symmetrical $\mathbf{R}_{\mathbf{1}}=\mathbf{R}_{\mathbf{2}}={ }^{12} \mathrm{CH}_{3}$ münchnone) is 1.08. While the quantitative significance of this number is difficult to ascribe, the index is consistent with the observed low regioselectivity. We conclude that the $\Delta \mathrm{E}_{\mathrm{ct}}$

Table IV. Cycloaddition Reactions of Isotopically Labelled Munchnones

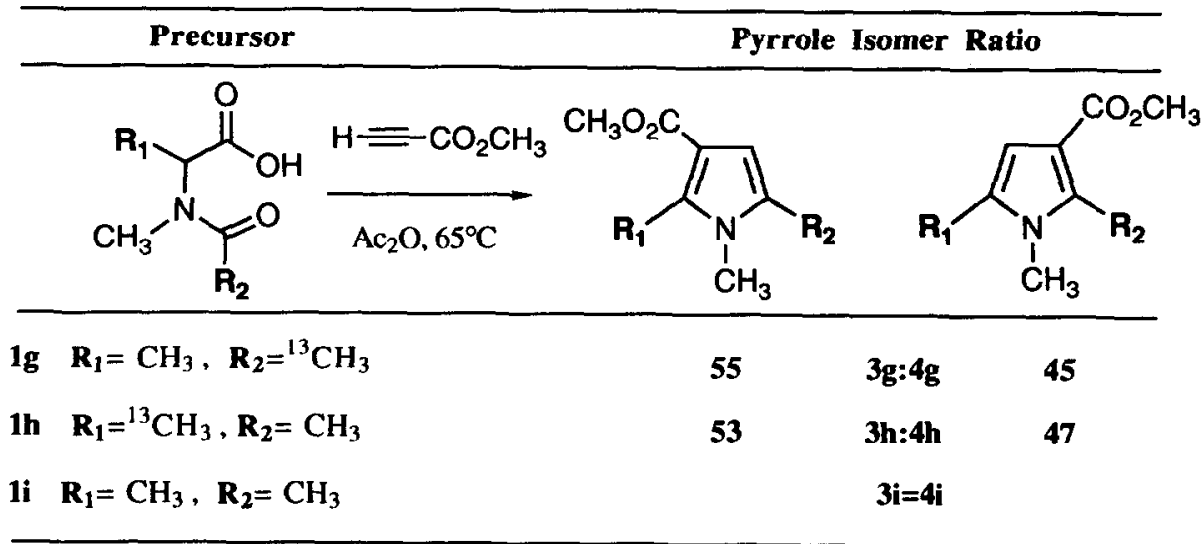


ratios for all of these examples might indeed reflect an authentic lack of FMO bias in the regioselectivity question for mesoionic compounds. This picture could indicate that most substituents simply do not possess enough perturbing effect to overcome either the Type II behavior and/or the electron-delocalization effect of the mesoionic heterocycle. The contribution that the unsymmetrical transition state model plays may also be limited to cases where at least one of the substituent groups is a hydrogen atom and the cycloaddition is irreversible, so that the various bond formations are differentiated enough to favor one of the pathways.

The Role of Non-Covalent Interactions. Two series of cycloadditions were performed in order to examine how important eclipsing interactions and transition state symmetry might be in determining regioselectivity. In the first, the structure of the dipolarophile was varied by changing the nature of the group attached to the $\beta$-carbon of the acetylenic ester. The phenylthio/hydrogen-substituted münchnone precursor 1d was heated with methyl 2-butynoate and methyl phenylpropiolate under the same conditions as with methyl propiolate. The results are presented in Table $\mathbf{V}$. There is a remarkable difference between the product distribution observed from the cycloaddition with methyl propiolate (entry 1) and that of methyl 2-butynoate (entry 2) in spite of the fact that the individual FMO characteristics for these two dipolarophiles are quite similar. Further modification by exchanging the B-methyl group for a B-phenyl group as in methyl phenylpropiolate ${ }^{35}$ (entry 3) leads to the cycloadduct $A$ with no evidence of the other regioisomer detectable by either spectroscopic or analytical HPLC methods. In these three cases, as is indeed true for all of the others reported so far, an unsymmetrical transition state where advanced bond formation favors the joining of the two least encumbered reacting termini can be used to predict the major regioisomer. The trend in A-values ${ }^{36}$ for the substituents on the dipolarophile is consistent with the trend in Table $\mathrm{V}\left[\mathrm{Ph}\right.$ (2.9) $>\mathrm{CH}_{3}$ (1.71) $>\mathrm{CO}_{2} \mathrm{CH}_{3}$ $(1.27-1.31)>\mathrm{H}]$.

TABLE V. Cycloaddition of 1d-derived Münchnone with Acetylenic Dipolarophiles

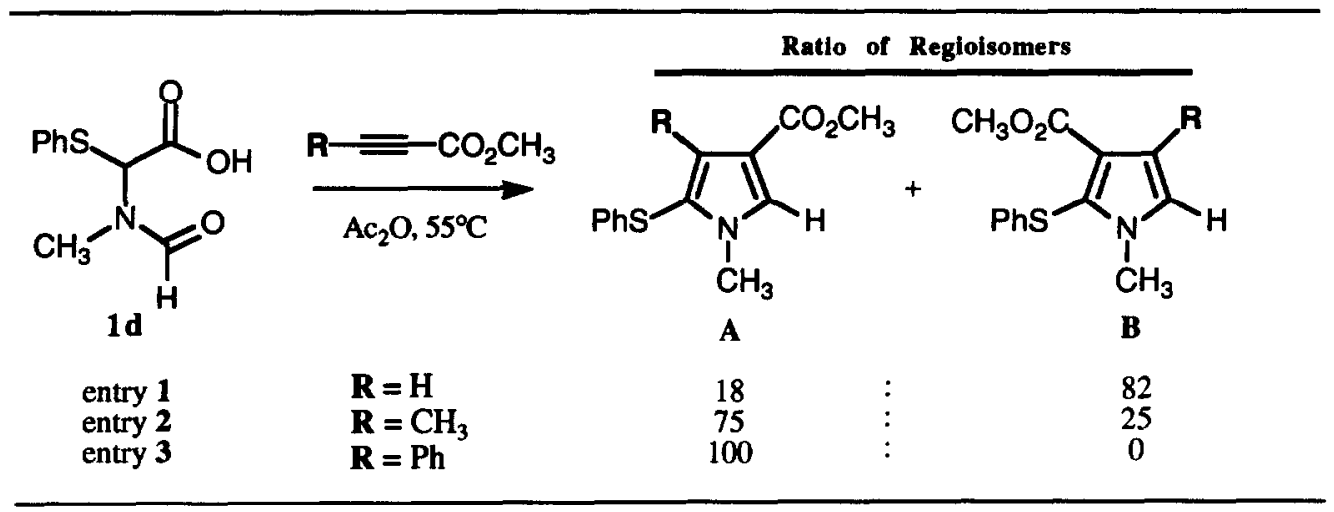

In the second series of cycloaddition reactions, the regioselectivities exhibited by a series of alkyl/alkyl substituted münchnones were compared to some alkyl/hydrogen compounds. The results of these cycloaddition reactions with methyl propiolate are presented in Table VI (entries 1-6), 37 along with four pertinent examples from earlier work in this report (entries $7,8,18,19$ ) and from the literature, including aryl/hydrogen and aryl/alkyl substituted münchnones (entries 9-17). ${ }^{9}, 10 \mathrm{a}$ In those cases where one of the 
Table VI. Summary of Unsymmetrical Munchnone Cycloadditions with Methyl Propiolate

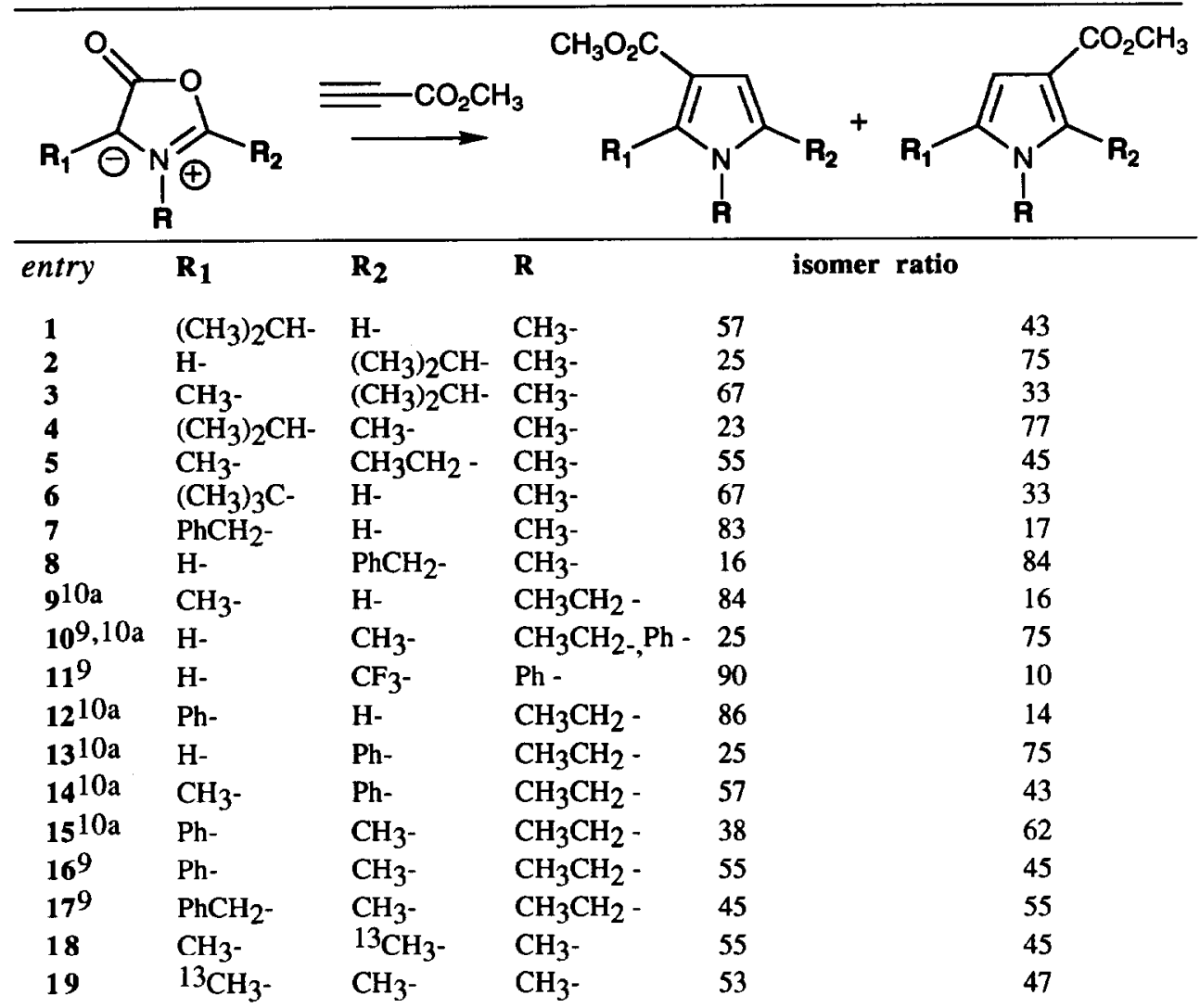

münchnone substituents is a hydrogen atom, there is a consistent trend to produce the 3-pyrrolecarboxylate isomer as the major product. This is true for the hydrogen/alkyl pairs (entries 1, 2, 6, 7, 8, 9, 10), hydrogen/thioaryl pairs (see Table I), and hydrogen/aryl pairs (entries 12 and 13). As mentioned before, the hydrogen/trifluoromethyl methyl example (entry 11) stands as the lone exception. In the examples of alkyl/alkyl pairs (entries $3,4,5,17-19$ ), an opposite sort of selectivity is observed. Using the methyl/methyl case (entries 18-19) as the starting point, the methyl/ethyl pair (entry 5) and the methyl/isopropyl pair (entries 3 and 4) show a consistent trend to form the less crowded isomer as the major product to an increasing extent. Here, where one of the münchnone substituents is not a hydrogen atom, we propose that a more synchronous set of bond formations is required relative to the hydrogen/alkyl compounds (see Figure 1). Without a dominant FMO interaction to guide the regioselectivity, the favored transition state is simply the one that has the lower set of non-covalent interactions when considering both pairs of termini combining in a symmetrical fashion. The number of aryl/alkyl examples is too limited to make a generalization (entries 14, 15, and 16), and there is some inconsistency in those reported regioisomeric ratios (entries 15 and 16). 
We have not included any further discussion thus far about münchnones that are part of bicyclic ring systems, which exhibit completely regioselective cycloaddition reactions with methyl propiolate (see eq. 4). The cycloaddition reactions with the münchnones ${ }^{14}$ derived from $\mathrm{N}$-formylproline and $\mathrm{N}$-formyl(homoproline) can be viewed as hydrogen/alkyl cases where the alkyl substituent is intramolecularly tethered back to the central nitrogen atom (eq. 4.). The regioselectivities with methyl propiolate cycloadditions completely favor the isomer where the two hydrogen atom termini end up bonded in the pyrrole ring of the product. In the $\mathrm{N}$ acetylproline and $\mathrm{N}$-acetyl(homoproline) experiments reported by the same authors, which may be viewcd as alkyl/alkyl cases where one of the chains is tethered back, the selectively is complete, and in the same sense as the $\mathrm{N}$-formyl derivatives. We consider these examples (especially the latter, when compared with the alkyl/alkyl examples in Table VI) to strongly support the view of an asynchronous transition state, where the comparative ease of an initial bond formation differentiates between the two modes of cycloaddition. In these cases, the relative flexibility of the non-tethered terminus allows for a greater degree of bonding in a transition state with a highly Michael-like character. We have investigated this tethering of substituents with regard to the regioselectivity question and have observed a clear and consistent trend favoring highly regioselective cycloadditions. 38

Computational Transition State Search. We have also performed a computational search for the transition state structures arising from the two possible cycloaddition orientations for one of our muinchnones 2b with methyl propiolate. Transition state geometries (Figure 2) were located with the SADDLE option using the MNDO Hamiltionian parameters of MOPAC (Version 6.0), and refined by Baker's method. ${ }^{39}$ Both of the transition states were characterized by one negative force constant and gradient values of 1.9 (formation

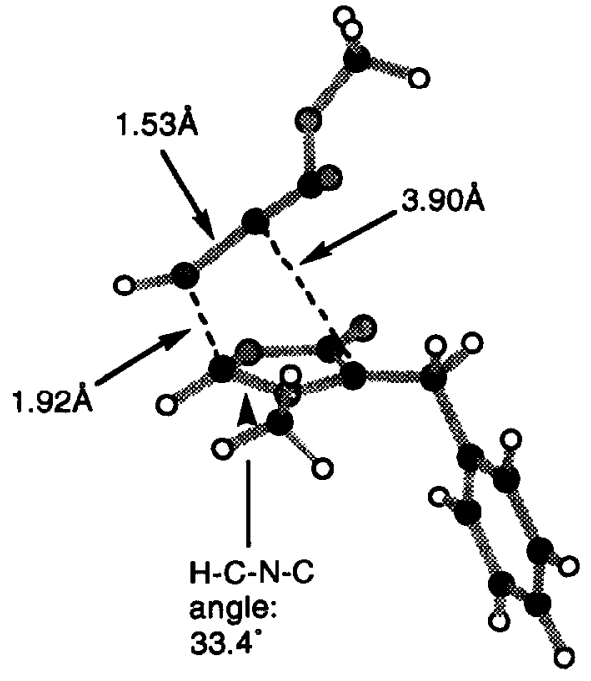

$2 b \rightarrow->4 b(84 \%)$

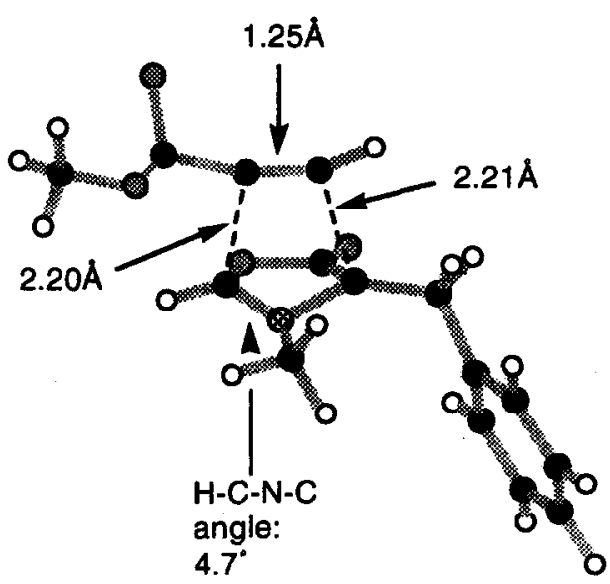

$2 b->->3 b(16 \%)$

Figure 2. Calculated Transition State Structures for Münchnone 2b plus Methyl Propiolate Intermediates leading to $3 \mathrm{~b}$ and $4 \mathrm{~b}$. 
of major isomer $\mathbf{4 b}$ ) and 14.8 (formation of minor isomer $\mathbf{3 b}$ ). The results from these calculations are consistent with the picture we predicted from the experimental work. In the case of the orientation leading to the observed major product $\mathbf{4 b}$, a highly asynchronous cycloaddition with a Michael-like character results. In this case, the 'nucleophilic' terminus of the münchnone is the one with the hydrogen substituent. In the case of the orientation leading to the observed minor product $3 \mathbf{b}$, a more synchronous cycloaddition reminiscent of the prediction for the alkyl/alkyl cases results. This transition state is also calculated to have a higher energy than the one depicted for the major regioisomer. Supporting evidence for an unsymmetrical transition state structure can be found in the theoretical analysis of Quast's stepwise azide reaction, ${ }^{6}$ where the calculated bond distances $(3.11 \AA$ and $1.97 \AA)$ are comparable to ours. In related work, 38 we have proposed that a transition state with a high Michael-like character is also required to explain the regioselectivity derived from a set of polycyclic compounds.

\section{CONCLUSION}

No single criterion can successfully be used to correlate the experimental observations regarding the regioselectivity in münchnone cycloaddition reactions. As others in this area have concluded, both the steric and electronic properties of the münchnone substituents must be considered. However, the FMO contribution appears to be minimally responsible in the cases investigated here. These examples also suggest the importance of considering the molecular flexibility towards a favorable, unsymmetrical transition state. As Houk has stated, the lack of information directly related to the 1,3-dipolar cycloaddition transition state is an enormous hindrance to a more complete understanding of the process. 40

By creating a better model for correlating the factors responsible for the regioselectivity, the construction of more predictable regiocontrol elements is possible. Additional investigations along these lines are currently in progress, and they will reported in due course.

Acknowledgements. We thank the National Science Foundation for their generous support of the thioaryl-substituted münchnone work, and the University of Michigan Chemistry Department for their continued support of our program. We thank the Wisconsin Alumni Research Fund for the Graduate Fellowship for BPC (1978-1980), and the University of Michigan Chemistry Department for the Gomberg Summer Undergraduate Fellowship for MCN (1990). We gratefully acknowledge Mr. Stanley J. Szwast for performing some of the preliminary experiments, and Dr. David Seeger for helpful discussions regarding the computational work.

\section{EXPERIMENTAL}

General Methods. Unless otherwise specified, all reactions were carried out in flame-dried glassware under a positive atmosphere of dry nitrogen. Toluene and acetonitrile were distilled from $\mathrm{CaH}_{2}$ prior to use. Acetic anhydride was distilled from $\mathrm{CaC}_{2}$ prior to use. $\mathrm{N}, \mathrm{N}$-Dimethyl formamide was distilled from $\mathrm{BaO}$ prior to use. THF was freshly distilled from sodium/benzophenone. Proton and carbon nuclear magnetic resonance spectra $\left({ }^{1} \mathrm{H}\right.$ - and ${ }^{13} \mathrm{C}$-NMR) were recorded on a Bruker AM 300, Bruker AM 360 or on a Varian $200 \mathrm{MHz}$ spectrometer. Infrared spectroscopy was performed on a Nicolet 5DX Spectrometer. Mass Spectroscopy was obtained using $70 \mathrm{eV}$ electron impact ionization or chemical ionization (CI) and quadrapole moment detection. Ultraviolet spectroscopy was performed on a Cary 17 instrument. 
Starting Materials. Methyl propiolate, methyl 2-butynoate, dimethyl acetylenedicarboxylate and methyl phenylpropiolate were obtained commercially and distilled before use. Thiophenols were distilled from calcium hydride. Glyoxylic acid and amino acids were obtained commercially (Aldrich Chemical Company). Amidoalkylation reactions were performed as described by Zoller. 22

N-Formyl-N-methylphenylalanine (1a): Compound 1a was prepared by the method of Quitt $21 \mathrm{a}$ to give $83 \%$ of a white solid, mp. $180^{\circ} \mathrm{C}$ (lit. $181-2^{\circ} \mathrm{C}$ ). IR (KBr): $3300,3070,1735,1650,1250,1055,1040$, $770,690 \mathrm{~cm}^{-1} ;{ }^{1} \mathrm{H}-\mathrm{NMR}$ (DMSO-d 6 , as rotamers) : $\delta 1.95,2.00(3 \mathrm{H}, \mathrm{s}), 2.19,2.28(2 \mathrm{H}, \mathrm{s}), 2.60(2 \mathrm{H}, \mathrm{m})$, 4.10, $4.50(1 \mathrm{H}, \mathrm{dd}, \mathrm{J}=8,4 \mathrm{~Hz}), 6.80(10 \mathrm{H}, \mathrm{bs}), 7.16,7.30(1 \mathrm{H}, \mathrm{s})$; MS (m/e, \%): $207(0.6), 192(3), 179$ (19), 156 (57), 148 (63); exact mass calculated for $\mathrm{C}_{11} \mathrm{H}_{13} \mathrm{NO}_{3}$ : 207.0892; found: 207.0894 .

N-Methyl-N-(phenylacetyl)glycine $(1 \mathrm{~b})^{21 b}$ : To a stirred, room temperature solution of $\mathrm{N}$ methylglycine $(4.5 \mathrm{~g}, 51 \mathrm{mmo1})$ in chloroform $(50 \mathrm{~mL})$ and tetrahydrofuran $(10 \mathrm{~mL})$ was added trimethylchlorosilane $(5.53 \mathrm{~g}, 6.5 \mathrm{~mL}, 51 \mathrm{mmol})$ The resulting solution was stirred for $3 \mathrm{hr}$ at $65^{\circ} \mathrm{C}$, then cooled to $-10^{\circ} \mathrm{C}$. To this cooled solution was added phenylacetyl chloride $(7.87 \mathrm{~g}, 51 \mathrm{mmol})$ followed by dropwise addition of triethylamine $(10.3 \mathrm{~g}, 14.2 \mathrm{~mL}, 0.102 \mathrm{~mol})$. Stirring was continued at $-10^{\circ} \mathrm{C}$ for $30 \mathrm{~min}$, after which time the mixture was poured into a separatory funnel containing $10 \mathrm{~mL}$ of $10 \%$ aqueous hydrochloric acid. The organic layer was washed with $3 \times 10 \mathrm{~mL}$ of $10 \%$ aqueous hydrochloric acid, $1 \times 10$ $\mathrm{mL}$ of water, separated and dried $\left(\mathrm{MgSO}_{4}\right)$. Evaporation of the solvents yielded $8.0 \mathrm{~g} \mathrm{(76 \% )}$ of $1 \mathrm{~b}$ as a waxy solid. Recrysta1lization (ethanol/water) gave $7.5 \mathrm{~g} \mathrm{(70 \% )}$ of clear needles, $\mathrm{mp} .150-1^{\circ} \mathrm{C}$. IR (KBr): 3200 , $3010,1610,1450,1420,1205 \mathrm{~cm}^{-1}$; ${ }^{1} \mathrm{H}-\mathrm{NMR}$ ( $\mathrm{CDCl}_{3}$, as rotamers) $82.95,3.0(3 \mathrm{H}, \mathrm{s}), 3.64,3.76(2 \mathrm{H}$, s), 3.96, 4.10 (2H s), 7.24 (5H, m); MS (m/e, \%): 207 (1) 192 (30) 175 (20) 163 (45) 146 (20), 128 (50), 97 (90); exact mass calculated for $\mathrm{C}_{11} \mathrm{H}_{13} \mathrm{NO}_{3}: 207.0892$; found: 207.0889 .

$\alpha$-Hydroxy-N-formyl-N-methylglycine (1j): A solution of glyoxylic acid monohydrate (3.32 $\mathrm{g}, 36$ mmol) and $\mathrm{N}$-methyl formamide $(2.13 \mathrm{~g}, 35 \mathrm{mmol})$ was refluxed for $24 \mathrm{~h}$ in $70 \mathrm{~mL}$ of acetone. After cooling the mixture to room temperature, the solvent was evaporated to yield $4.7 \mathrm{~g}(97 \%)$ of the title compound as a waxy solid. While the product was generally used directly in the amidoalkylation reactions, a sample was recrystallized from chloroform/dioxane to give white needles, mp. 10l-30 C. IR (KBr) $3330,1730,1610 \mathrm{~cm}^{-1}$; ${ }^{1} \mathrm{H}-N M R$ (DMSO-d 6 , as rotamers): $82.68,2.88(3 \mathrm{H}, \mathrm{s}) 5.52,5.92(1 \mathrm{H}, \mathrm{s}), 8.08,8.22(1 \mathrm{H}, \mathrm{s}), 8.7(2 \mathrm{H}, \mathrm{bs})$; MS (m/e, \%) $133(2), 132(1), 118(3), 115(29), 112(10), 105$ (19), 98 (21), 89 (79); exact mass calculated for $\mathrm{C}_{4} \mathrm{H}_{7} \mathrm{NO}_{4}$ : 133.0373; found: 133.0372 .

General Procedure for Amidoalkylations A: To a stirred, $0^{\circ} \mathrm{C} 1 \mathrm{M}$ suspension of $\alpha$-hydroxy-N-acyl-Nalkylglycine in glacial acetic acid was added 4 equivalents of the thiol to be amidoalkylated. To this stirred suspension was added, dropwise, concentrated sulfuric acid (1 mL for every $10 \mathrm{~mL}$ of suspension). The resulting mixture was generally homogeneous within $12 \mathrm{~h}$ after stirring at room temperature. After an additional 1.5 days, the reaction mixture was poured into $70 \mathrm{~g}$ of ice. The organic products were extracted with $4 \times 20 \mathrm{~mL}$ of ethyl acetate. The organic solution was then washed with $2 \times 50 \mathrm{~mL}$ of water, followed by extraction with $5 \times 30 \mathrm{~mL}$ of $5 \%$ aqueous sodium bicarbonate. The combined aqueous extracts were washed with $3 \times 30 \mathrm{~mL}$ of ether, acidified with concentrated hydrochloric acid, and extracted with $4 \times 20 \mathrm{~mL}$ of ethyl acetate. The organic extracts were combined, dried $\left(\mathrm{MgSO}_{4}\right)$ and evaporated to yield the amidoalkylated products as white solids; recrystallization could be effected with chloroform/ether or ethyl acetate/hexane mixtures, although the products were generally of sufficient purity to utilize directly.

General Procedure for Amidoalkylations B: To a stirred, $0.3 \mathrm{M}$ solution of the appropriate glycine derivative in 1,2-dichloroethane was added 1 equivalent of the thiol to be amidoalkylated, followed by $50-100$ $\mathrm{mg}$ of $\beta$-naphthalenesulfonic acid. The resulting solution was heated at $90^{\circ} \mathrm{C}$ for $48 \mathrm{hr}$. After cooling to room temperature, the reaction mixture was washed with $3 \times 25 \mathrm{~mL}$ of water, dried $\left(\mathrm{MgSO}_{4}\right)$ and evaporated to yield off-white to yellow solids which could be purified as described in Procedure A. 
$\alpha-(4 '-M e t h o x y p h e n y l t h i o)-N-f o r m y l-N-m e t h y l g l y c i n e(1 c)$ : Compound $1 c$ was prepared from $1 \mathrm{j}$ $(3.3 \mathrm{~g}, 24 \mathrm{mmol})$ and 4 '-methoxythiophenol $(12.0 \mathrm{~g}, 97 \mathrm{mmol})$ via general procedure A for the amidoalkylation of thiols as a white solid $(3.6 \mathrm{~g}, 62 \%), \mathrm{mp} 137-9{ }^{\circ} \mathrm{C}$. IR (KBr): $3220,1720,1630,1300$, $1170,1050 \mathrm{~cm}^{-1}$; ${ }^{1} \mathrm{H}$-NMR (DMSO-d6, as rotamers): $\delta 2.76(3 \mathrm{H}, \mathrm{s}), 3.76(3 \mathrm{H}, \mathrm{s}), 6.0,6.28,(1 \mathrm{H}, \mathrm{s}), 6.9$ $(2 \mathrm{H}, \mathrm{d}, \mathrm{J}=8 \mathrm{~Hz}), 7.20(2 \mathrm{H}, \mathrm{d}, \mathrm{J}=8 \mathrm{~Hz}), 7.6,7.96(1 \mathrm{H}, \mathrm{s}) ; \mathrm{MS}(\mathrm{m} / \mathrm{e}, \%): 255(3), 227(9), 211(17), 181$ $(37), 157(45), 148(36), 139(56), 136(55), 116(81), 98(15)$; exact mass calculated for $\mathrm{C}_{11} \mathrm{H}_{13} \mathrm{NO}_{4} \mathrm{~S}$ : 255.0562 ; found: 255.0562 .

$\alpha-P h e n y l t h i o-N$-formyl-N-methylglycine (1d): Compound 1d was prepared from $1 \mathrm{j}$ (717 mg, 5.38 $\mathrm{mmol}$ ) and thiophenol $(2.4 \mathrm{~g}, 21.6 \mathrm{mmol})$ via general procedure $\mathrm{A}$ for the amidoalkylation of thiols as white crystals $(0.93 \mathrm{~g}, 72 \%)$, mp. $212^{\circ} \mathrm{C}$. IR (KBr): $3300,1710,1620,1520,1440,1330,1110,750,690 \mathrm{~cm}^{-1}$; ${ }_{1}$ H-NMR (DMS0-d6, as rotamers): $82.70,2.96(3 \mathrm{H}, \mathrm{s}), 6.24,6.50(1 \mathrm{H}, \mathrm{s}), 7.40(5 \mathrm{H}, \mathrm{bm}), 7.76,8.04(1 \mathrm{H}$, s); MS (m/e, \%): $225(0.5), 223(0.1), 197$ (30), $196(35), 185(40), 181(56), 157(16), 116(63), 110(83)$; exact mass calculated for $\mathrm{C}_{10} \mathrm{H}_{11} \mathrm{NO}_{3} \mathrm{~S}: 225.0457$; found: 225.0452 .

$\alpha$-(3'-Trifluoromethylphenylthio)-N-formyl-N-methylglycine (1e): Compound le was prepared from $1 \mathrm{j}(1.2 \mathrm{~g}, 9.2 \mathrm{mmol})$ and 3 -trifluoromethylthiophenol $(1.8 \mathrm{~g}, 10.1 \mathrm{mmol})$ via general procedure $B$ for the amidoalkylation of thiols. The initial viscous oil (98\%) crystallized upon standing to give $1.2 \mathrm{~g} \mathrm{(85 \% ,} \mathrm{after}$ washing with cold ether) of an off-white solid, mp 170-30 C. IR ( $\left.\mathrm{CDCl}_{3}\right): 3100,1730,1685,1330,1170$, $1150,1065,1045 \mathrm{~cm}^{-1}$; $1 \mathrm{H}-\mathrm{NMR}$ (CDCl 3 , as rotamers): $82.88,3.02(3 \mathrm{H}, \mathrm{s}), 5.65,6.64(1 \mathrm{H}, \mathrm{s}), 7.70$ $(4 \mathrm{H}, \mathrm{bm}), 7.88,8.0(1 \mathrm{H}, \mathrm{s}) ; \mathrm{MS}(\mathrm{m} / \mathrm{e}, \%) 293(0.1), 286(0.5), 275(15), 249(35), 235(19), 198(57) 113$ (68); exact mass calculated for $\mathrm{C}_{11} \mathrm{H}_{10} \mathrm{~F}_{3} \mathrm{NO}_{3} \mathrm{~S}: 293.0331$; found: 293.0332 .

$\alpha$-(4-Nitrophenylthio)-N-formyl-N-methylglycine (10): Compound 1f was prepared from 1j (2.35 $\mathrm{g}, 17 \mathrm{mmol})$ and 4 -nitrothiophenol $(2.74 \mathrm{~g}, 18 \mathrm{mmol})$ via general procedure $B$ for the amidoalkylation of thiols as a pale yellow solid $(4.4 \mathrm{~g}, 92 \%) \mathrm{mp} 64-6^{\circ} \mathrm{C}$. IR $(\mathrm{CDCl} 3): 3100,1730,1535,1330,1150,1060$ $\mathrm{cm}^{-1}$; ${ }^{1} \mathrm{H}-\mathrm{NMR}$ (DMSO-d6, as rotamers): $\delta 2.78,2.98(3 \mathrm{H}, \mathrm{s}), 5.98,6.00(1 \mathrm{H}, \mathrm{s}), 6.45,6.74(1 \mathrm{H}, \mathrm{s}), 7.6$ $(2 \mathrm{H}, \mathrm{m}), 8.1(2 \mathrm{H}, \mathrm{m})$; MS (m/e, \%): $270(1), 181(0.1), 169(0.4), 155(100), 125$ (31), 109 (49), 69 (46); exact mass calculated for $\mathrm{C}_{10} \mathrm{H}_{10} \mathrm{~N}_{2} \mathrm{O}_{5} \mathrm{~S}$ : 270.0303 ; found: 270.0306 .

General Procedure for Cycloaddition reactions with acetylenic dipolarophiles. All of the cycloaddition reactions of precursors 1a-i with methyl propiolate, methyl 2-butynoate or methyl phenylpropiolate were performed as follows: To a $0.5 \mathrm{M}$ mixture of amidoacid (3-10 mmol scale) in acetic anhydride was added a 5 molar excess of the dipolarophile. The resulting suspension was heated to $55^{\circ}$; solution generally occurred within 5 to 10 minutes. After stirring for $24 \mathrm{~h}$ at $55^{\circ} \mathrm{C}$, solvents and excess dipolarophile were removed via distillation at reduced pressure $(0.01-0.1 \mathrm{~mm} \mathrm{Hg})$. The material thereby obtained was directly subjected to analytical HPLC and NMR analyses. 23 The pyrrole regioisomers were generally inseparable by preparative thin layer chromatographic techniques. Yields of pyrrole products were consistently good to excellent on all reaction scales.

Methyl 2-benzyl-1-methyl-3- and 4-pyrrolecarboxylate $(3 a=4 b$ and $4 a=3 b)$.

A. Reaction of la $(153 \mathrm{mg}, 0.74 \mathrm{mmol})$ with methyl propiolate $(280 \mathrm{mg}, 3.3 \mathrm{mmol})$ under cycloaddition conditions gave $173 \mathrm{mg}(95 \%)$ of a $5.0: 1$ mixture of 3a:4a. Chromatographic (preparative TLC plate; $1: 1$ ether; hexane/1\% AcOH; 3 elutions) separation yielded the two isomers $\left(3 a, R_{f}=0.25 ; 4 a, R_{f}=0.29\right)$ as clear oils.

3a: IR (CDC13) : 1700, 1500, 1440, 1260, $1140 \mathrm{~cm}^{-1}$; ${ }_{1} \mathrm{H}$-NMR (3-isomer, $\mathrm{CDCl}_{3}$ ): $83.24(3 \mathrm{H}, \mathrm{s}), 3.68$ $(3 \mathrm{H}, \mathrm{s}), 4.32,(2 \mathrm{H}, \mathrm{s}), 6.26(1 \mathrm{H}, \mathrm{bd}, \mathrm{J}=2 \mathrm{~Hz}), 6.5(1 \mathrm{H}, \mathrm{bd}, \mathrm{J}=2 \mathrm{~Hz}), 7.05(5 \mathrm{H}, \mathrm{m}) ; \mathrm{MS}(\mathrm{m} / \mathrm{e}, \%): 229(1)$, 214 (13) $206(10), 198(15)$; exact mass calculated for $\mathrm{C}_{14} \mathrm{H}_{15} \mathrm{NO}_{2}: 229.1099$; found: 229.1100 . 
4a: IR (CDCl3): $1705,1500,1400,1250 \mathrm{~cm}^{-1} ;{ }^{1} \mathrm{H}-\mathrm{NMR}\left(\mathrm{CDCl}_{3}\right): 83.68(3 \mathrm{H}, \mathrm{s}), 3.96(3 \mathrm{H}, \mathrm{s}), 4.04(2 \mathrm{H}$, s), $6.42(1 \mathrm{H}, \mathrm{bs}), 7.2(6 \mathrm{H}, \mathrm{bm}) ; \mathrm{MS}(\mathrm{m} / \mathrm{e}, \%): 229(0.5), 219(19), 206(10), 205(8), 198(23), 168(35)$; exact mass calculated for $\mathrm{C}_{14} \mathrm{H}_{15} \mathrm{NO}_{2}: 229.1099$; found: 229.1099 .

B. Reaction of $1 \mathrm{~b}(248 \mathrm{mg}, 1.2 \mathrm{mmol})$ with methyl propiolate $(450 \mathrm{mg}, 5.3 \mathrm{mmol})$ under cycloaddition conditions gave $268 \mathrm{mg}(91 \%)$ of a $4.8: 1$ mixture of $4 \mathrm{~b}: 3 \mathrm{~b}$ which were separable and spectroscopically identical to those from part $A$.

Methyl 2-(4'-methoxyphenylthio)-l-methyl-3- and 4-pyrrolecarboxylate (3c and 4c): Reaction of $1 \mathrm{c}(461 \mathrm{mg}, 1.9 \mathrm{mmol})$ with methyl propiolate $(730 \mathrm{mg}, 8.7 \mathrm{mmol})$ under cycloaddition conditions gave $520 \mathrm{mg}(91 \%)$ of $3 \mathrm{c}$ and $4 \mathrm{c}$, partially separable (preparative TLC; 1:3 EtOAc: hexane; 3 elutions; $\left(3 \mathrm{c}, \mathrm{R}_{\mathrm{f}}=\right.$ $0.32 ; 4 c, R_{f}=0.35$ ) as clear oils.

3c: IR (CDC13): 2970, 2920, 1705, 1600, 1500, 1250, $1040 \mathrm{~cm}^{-1}$; ${ }^{1} \mathrm{H}-\mathrm{NMR}$ (CDC13): 83.59 (3H, s), 3.72 $(3 \mathrm{H}, \mathrm{s}), 3.79(3 \mathrm{H}, \mathrm{s}), 6.67(1 \mathrm{H}, \mathrm{d}, \mathrm{J}=3.2 \mathrm{~Hz}), 6.75(1 \mathrm{H}, \mathrm{d}, \mathrm{J}=3.2 \mathrm{~Hz}), 7.1(2 \mathrm{H}, \mathrm{m}), 7.3(2 \mathrm{H}, \mathrm{m})$; MS (3isomer, $\mathrm{m} / \mathrm{e}, \%$ ): $277(4), 262(25), 246(29), 231(30), 195$ (16); exact mass calculated for $\mathrm{C}_{14} \mathrm{H}_{15} \mathrm{NO}_{3} \mathrm{~S}$ : 277.0769; found: 277.0772 .

4c: IR (CDCl3): 2970, 2920, 1705, 1495, 1250, $1040 \mathrm{~cm}^{-1}$; $1 \mathrm{H}-\mathrm{NMR}\left(\mathrm{CDCl}_{3}\right): 83.59$ (3H, s), 3.75 (3H, s), $3.8(3 \mathrm{H}, \mathrm{s}), 7.05(2 \mathrm{H}, \mathrm{m}) 7.07(\mathrm{H}, \mathrm{d}, \mathrm{J}=2 \mathrm{~Hz}), 7.11(2 \mathrm{H}, \mathrm{m}), 7.42(1 \mathrm{H}, \mathrm{d}, \mathrm{J}=2 \mathrm{~Hz}) ; \mathrm{MS}(\mathrm{m} / \mathrm{e}, \%): 227$ (0.3), $262(19), 246(30), 230(18), 195$ (20), 168 (39); exact mass calculated for $\mathrm{C}_{14} \mathrm{H}_{15} \mathrm{NO}_{3} \mathrm{~S}: 277.0769$; found: 277.0761 .

Methyl 1-methyl-1-phenylthio-3- and 4-pyrrolecarboxylate (3d and 4d): Reaction of 1d (320 $\mathrm{mg}, 1.4 \mathrm{mmol}$ ) with methyl propiolate $(540 \mathrm{mg}, 6.4 \mathrm{mmol}$ ) under cycloaddition conditions gave $350 \mathrm{mg}$ (93\%) of the 3d and $4 d$ as a viscous oil. IR (CDCl3) : 1700, 1490, $1240 \mathrm{~cm}^{-1} ;{ }_{1} \mathrm{H}-\mathrm{NMR}\left(3^{*}+4\right.$-isomer, $\left.\mathrm{CDC1}_{3}\right): 83.55^{*}(3 \mathrm{H}, \mathrm{s}), 3.75^{*}(3 \mathrm{H}, \mathrm{s}), 6.72 *(1 \mathrm{H}, \mathrm{d}, \mathrm{J}=2.5 \mathrm{~Hz}), 6.8^{*}(1 \mathrm{H} \mathrm{d}, \mathrm{J}=2.5 \mathrm{~Hz}), 7.0-7.1^{*}(6 \mathrm{H}$, $\mathrm{m}) ; 3.51(3 \mathrm{H}, \mathrm{s}), 3.78(3 \mathrm{H}, \mathrm{s}), 7.0-7.1(6 \mathrm{H}, \mathrm{m}), 7.47(\mathrm{H}, \mathrm{bs}) ; \mathrm{MS}(\mathrm{m} / \mathrm{e}, \%): 247(3), 232(19), 216(8)$, 201 (45), 192 (20), 169 (35), 135 (20); exact mass calculated for $\mathrm{C}_{13} \mathrm{H}_{13} \mathrm{NO}_{2} \mathrm{~S}: 247.0664$; found: 247.0666.

Methyl 1-methyl-1-(3-trifluoromethylphenylthio)-3- and 4-pyrrolecarboxylate (3e and 4e): Reaction of 1d $(229 \mathrm{mg}, 0.78 \mathrm{mmol})$ with methyl propiolate $(260 \mathrm{mg}, 3.12 \mathrm{mmol})$ under cycloaddition conditions gave $594 \mathrm{mg}(94 \%)$ of $3 e$ and $4 \mathrm{e}$ as inseparable oils. IR (CDCl3): 2970, 1700, 1485, 1320, 1250, $1170,1140 \mathrm{~cm}^{-1}$; ${ }^{1} \mathrm{H}-\mathrm{NMR}\left(3^{*}+\right.$ + 4-isomer, $\left.\mathrm{CDCl}_{3}\right): 83.62^{*}(3 \mathrm{H}, \mathrm{s}), 3.77^{*}(3 \mathrm{H}, \mathrm{s}), 6.77^{*}(1 \mathrm{H}, \mathrm{d}, \mathrm{J}=2.3)$, $6.88^{*}(1 \mathrm{H}, \mathrm{s}, \mathrm{J}=2.3 \mathrm{~Hz}), 7.1-7.3 *(3 \mathrm{H}, \mathrm{m}) ; 3.57(3 \mathrm{H}, \mathrm{s}), 3.82(3 \mathrm{H}, \mathrm{s}), 7.04(1 \mathrm{H}, \mathrm{bs}), 7.1-7.3(3 \mathrm{H}, \mathrm{m}) 7.53$ $(1 \mathrm{H}, \mathrm{bs}) ; \mathrm{MS}(\mathrm{m} / \mathrm{e}, \%): 315(3), 300(15), 284(30), 282(25), 194(30), 175(40), 165(25), 116(18) ;$ exact mass calculated for $\mathrm{C}_{14} \mathrm{H}_{12} \mathrm{~F}_{3} \mathrm{NO}_{2} \mathrm{~S}$ : 315.0586 ; found: 315.0554 .

Methyl 1-methyl-2-(4'-nitrophenylthio)-3- and 4-pyrrolecarboxylate (3f and 4f): Reaction of 1d $(340 \mathrm{mg}, 1.2 \mathrm{mmol})$ with methyl propiolate $(200 \mathrm{mg}, 2.4 \mathrm{mmol})$ under cycloaddition conditions gave 325 $\mathrm{mg}(93 \%)$ of $3 f$ and $4 f$ as inseparable oils. IR (CDC13): 2970,1700,1570,1515, 1470,1340,1240 $\mathrm{cm}^{-1}$; $1_{\text {H-NMR }}\left(3_{-+}^{*} 4\right.$-isomer, $\left.\mathrm{CDCl}_{3}\right): 83.66^{*}(\mathrm{~s}, 3 \mathrm{H}), 3.77^{*}(\mathrm{~s}, 3 \mathrm{H}), 6.8^{*}$ (d, J=3 Hz, 1H), 6.94* (d, J=3 Hz, $1 \mathrm{H}), 7.07 *(2 \mathrm{H}, \mathrm{d}, \mathrm{J}=9.5 \mathrm{~Hz}), 8.09 *(2 \mathrm{H} \mathrm{d}, \mathrm{J}=9.5 \mathrm{~Hz}) ; 3.6(3 \mathrm{H}, \mathrm{s}), 3.83(3 \mathrm{H}, \mathrm{s}), 7.07(2 \mathrm{H}, \mathrm{d}, \mathrm{J}=9.5 \mathrm{~Hz})$, $7.58(1 \mathrm{H}, \mathrm{bs}), 8.1(3 \mathrm{H}, \mathrm{m}) ; \mathrm{MS}(\mathrm{m} / \mathrm{e}, \%): 292(2), 277(10), 261(18), 233$ (30), 138 (49); exact mass calculated for $\mathrm{C}_{13} \mathrm{H}_{12} \mathrm{~N}_{2} \mathrm{O} 4 \mathrm{~S}: 292.0515$; found: 292,0486 .

N-Methylalanine, benzyl ester, hydrochloride salt (1ga): Compound 1ga was prepared by a modification of the procedure of Patel and Price. 41 To a stirred, $0^{\circ} \mathrm{C}$ mixture of $\mathrm{N}$-methylalanine $(2.88 \mathrm{~g}, 28$ $\mathrm{mmol}$ ) in benzyl alcohol $(50 \mathrm{~mL})$ was added, dropwise, thionyl chloride $(12 \mathrm{~mL}, 19.87 \mathrm{~g}, 167 \mathrm{mmol})$. The solution was stirred for $7 \mathrm{~h}$ at $95^{\circ}-100^{\circ} \mathrm{C}$. After cooling the solution to room temperature, ether was added to the solution until turbidity appeared. The mixture was refrigerated for 30 minutes and then filtered to give 4.78 $\mathrm{g}(88 \%)$ of the crude product as a fine white solid, m.p. $140^{\circ}-150^{\circ} \mathrm{C}$. The crude product $(4.66 \mathrm{~g})$ was dissolved in $50 \mathrm{~mL}$ of water. Solid sodium carbonate was added until $\mathrm{pH}$ 9. The aqueous mixture was extracted with ether $(3 \times 30 \mathrm{~mL})$ and the combined organic layers dried $\left(\mathrm{MgSO}_{4}\right)$. After filtration and dilution with ether to a volume of $150 \mathrm{~mL}$, the solution was saturated with $\mathrm{HCl}$ gas and refrigerated for 30 minutes. 
Filtration gave $2.59 \mathrm{~g}(56 \%)$ of $1 \mathrm{ga}$ as white solid, m.p. $162^{\circ}-165^{\circ} \mathrm{C}$. IR (KBr): $3475,2875,2710,1740$, $1250,1210,760,720 \mathrm{~cm}^{-1}$; ${ }_{1} \mathrm{H}$-NMR (CDCl 3$): \delta 1.60(3 \mathrm{H}, \mathrm{d}, \mathrm{J}=7 \mathrm{~Hz}), 2.65(3 \mathrm{H}, \mathrm{bs}), 3.85(1 \mathrm{H}, \mathrm{bs}), 5.20$ $(2 \mathrm{H}, \mathrm{m}), 7.30(5 \mathrm{H}, \mathrm{s}), 9.70(1 \mathrm{H}, \mathrm{bs}), 10.30(1 \mathrm{H}, \mathrm{bs})$; MS (m/e, \%): 194 (s), 91 (12), 58 (100), 36 (15); exact mass calculated for $\mathrm{C}_{11} \mathrm{H}_{16} \mathrm{NO}_{2}$ : 194.1181 ; found: 194.1170 .

$\mathrm{N}$-Acetyl-N-methylalanine, benzyl ester (1gb): Compound $1 \mathrm{gb}$ was prepared by a modification of the procedure of Bonner and McNamee. 42 To a mixture of $1 \mathrm{ga}(0.733 \mathrm{~g}, 3.20 \mathrm{mmol})$ in ethyl acetate $(25 \mathrm{~mL})$ was added triethylamine $(1.30 \mathrm{~mL}, 9.29 \mathrm{mmol})$. The organic layer was extracted with saturated, aqueous sodium chloride $(3 \times 25 \mathrm{~mL})$, and dried $\left(\mathrm{Na}_{2} \mathrm{SO}_{4}\right)$. The solution was filtered and solvents removed in vacuo to give the 1gb as a light yellow oil. A small amount of methylene chloride (ca. $5 \mathrm{~mL}$ ) was immediately added to the product. The methylene chloride solution was drawn into a syringe and equally distributed (by volume) into two flasks, one for the ${ }^{12} \mathrm{C}$-acetylation control reaction and one for the ${ }^{13} \mathrm{C}$-acetylation reaction $(.309 \mathrm{~g}$, $1.60 \mathrm{mmol}$ of amino ester per reaction) used to prepare $1 \mathrm{gc}$.

$\mathrm{N}-2-13 \mathrm{C}$-Acetyl-N-methylalanine, benzyl ester (1gc): To a stirred solution of dicyclohexylcarbodiimide $(0.463 \mathrm{~g}, 12.25 \mathrm{mmol})$ in methylene chloride $(12 \mathrm{~mL})$ was added, dropwise, a solution of acetic acid (acetic-2-13 C acid, $0.092 \mathrm{~g}, 1.53 \mathrm{mmol})$ in methylene chloride $(2 \mathrm{~mL})$ over 15 minutes. Dicyclohexylurea formed as a white precipitate within 5 minutes after the beginning of the addition. After the mixture was stirred for $1.5 \mathrm{~h}$, a $15 \mathrm{~mL}$ portion of pentane was added The mixture was cooled to $0^{\circ} \mathrm{C}$ and filtered. The filtrate was immediately added to the previously-prepared solution of $1 \mathrm{gb}$ that had been reserved for ${ }^{13} \mathrm{C}$-acetylation. Dicyclohexylurea again precipitated within 15 minutes after mixing. The mixture was stirred for $24 \mathrm{~h}$, after which a $10 \mathrm{~mL}$ portion of pentane was added. The mixture was cooled to $0^{\circ} \mathrm{C}$ and filtered. Evaporation of the solvents gave $0.497(138 \%)$ of a light yellow oil. The crude product was dissolved in $1-2 \mathrm{~mL}$ ethyl acetate, run through a filter pipet (silica gel) to remove a small amount of insoluble impurities, and then flash chromatographed $\left(2: 1\right.$ ethyl acetate:hexane; $\left.R_{f}=0.33\right)$. Compound $1 \mathrm{ge}(0.301 \mathrm{~g}, 61 \%)$ was obtained as an opaque white oil. IR (neat): $3470,2940,1745,1660,1405,1325,1215,1100,740,710 \mathrm{~cm}^{-1} ;{ }^{1} \mathrm{H}-\mathrm{NMR}$ $\left(\mathrm{CDCl}_{3}, 300 \mathrm{MHz}\right.$, major and minor* rotamer ratio ca. $\left.4: 1\right): 81.35,1.40^{*}\left(3 \mathrm{H} ; \mathrm{d}, \mathrm{J}=7 \mathrm{~Hz} ; \mathrm{d}^{*}, \mathrm{~J}=7 \mathrm{~Hz}\right), 2.05$ $(3 \mathrm{H}, \mathrm{d}, \mathrm{J}=130 \mathrm{~Hz}), 2.75^{*}, 2.90(3 \mathrm{H}, \mathrm{s}), 5.10(2 \mathrm{H}, \mathrm{m}), 4.45^{*}, 5.25\left(1 \mathrm{H} ; \mathrm{q}, \mathrm{J}=7 \mathrm{~Hz} ; \mathrm{q}^{*}, \mathrm{~J}=7 \mathrm{~Hz}\right), 7.30$ $(5 \mathrm{H}, \mathrm{m})$; MS (m/e, \%): $236(18), 192(1), 145(8), 101(41), 91(13), 58(100)$; exact mass calculated for $\mathrm{C}_{12}{ }^{13} \mathrm{CH}_{17} \mathrm{NO}_{3}: 236.1242$; found: 236.1237 .

$\mathrm{N}-2-13 \mathrm{C}$-Acetyl-N-methylalanine $(1 \mathrm{~g})$ : To a solution of $1 \mathrm{gb}(0.157 \mathrm{~g}, 0.662 \mathrm{mmol})$ in ethyl acetate $(20 \mathrm{~mL}$ ) was added 3-4 drops of glacial acetic acid and $5 \%$ palladium on carbon (ca. $4 \mathrm{mg}$ ). The mixture was stirred in a hydrogen atmosphere at a positive pressure for $16 \mathrm{~h}$, and then filtered through celite. Evaporation of the solvents gave $0.098 \mathrm{~g} \mathrm{(101 \% )}$ of $1 \mathrm{~g}$ as a white solid, m.p. 100-5 ${ }^{\circ} \mathrm{C}$. IR (KBr): 3440 (br), 2980 (br), $2580(\mathrm{br}), 1735,1610,1425,1270,1220,1110,1040,815 \mathrm{~cm}^{-1} ;{ }^{1} \mathrm{H}-\mathrm{NMR}\left(\mathrm{CDCl}_{3}, 300 \mathrm{MHz}\right.$, major and minor* rotamer ratio ca. $4: 1): \delta 1.35,1.45^{*}\left(3 \mathrm{H} ; \mathrm{d}, \mathrm{J}=7 \mathrm{~Hz} ; \mathrm{d}^{*}, \mathrm{~J}=7 \mathrm{~Hz}\right), 2.10(3 \mathrm{H}, \mathrm{d}, \mathrm{J}=135 \mathrm{~Hz}), 2.95^{*}$, 2.80 (3H; s*; s), 4.50*, $5.15\left(1 \mathrm{H} ; \mathrm{q}^{*}, \mathrm{~J}=7 \mathrm{~Hz} ; \mathrm{q}, \mathrm{J}=7 \mathrm{~Hz}\right) ; \mathrm{MS}(\mathrm{m} / \mathrm{e}, \%): 146(6), 102(12), 101(30), 58$ (100), 56 (14), 44 (24), 42 (13); exact mass calculated for $\mathrm{C}_{5}{ }^{13} \mathrm{CH}_{11} \mathrm{NO}_{3}$ : 146.0772 ; found: 146.0764.

Methyl 1,2,5-13 C-trimethylpyrrole-3-carboxylate $(3 \mathrm{~g})$ and Methyl 1,2-13 C,5-trimethylpyrrole-3-carboxylate $(4 \mathrm{~g})$ : To a stirred solution of $1 \mathrm{~g}(0.105 \mathrm{~g}, 0.724 \mathrm{mmol})$ in acetic anhydride (1.38 $\mathrm{mL}$ ) was added methyl propiolate $(0.232 \mathrm{~g}, 2.76 \mathrm{mmol})$. The solution was stirred at $55-65^{\circ} \mathrm{C}$ for $2.5 \mathrm{~h}$. Evaporation of the solvents and excess dipolarophile yielded $103 \mathrm{mg}(85 \%)$ of the crude product as a beige solid. Flash chromatography $\left(2: 1\right.$ hexane:ethyl acetate; $\left.R_{f}=0.42\right)$ gave $14 \mathrm{mg}(17 \%)$ of a white solid, $\mathrm{m} . \mathrm{p}$. $115-116.5^{\circ} \mathrm{C}$. The isomers are not chromatographically separable. IR (KBr): $3130,2950,1690,1535,1230$, $1190,1075 \mathrm{~cm}^{-1}$; the $3 \mathrm{~g}: 4 \mathrm{~g}^{*}$ isomer ratio were determined from both ${ }^{1} \mathrm{H}$ - and ${ }^{13} \mathrm{C}$-nmr integration as $55: 45^{*}$; $1_{\mathrm{H}-\mathrm{NMR}}\left(\mathrm{CDCl}_{3}\right): \delta 2.18\left(3 \mathrm{H} ; \mathrm{d}, \mathrm{J}=135 \mathrm{~Hz} ; \mathrm{s}^{*}\right), 2.50\left(3 \mathrm{H} ; \mathrm{s} ; \mathrm{d}^{*}, \mathrm{~J}=135 \mathrm{~Hz}\right), 3.39(3 \mathrm{H}, \mathrm{s}), 3.78(3 \mathrm{H}, \mathrm{s})$, $6.23(1 \mathrm{H}, \mathrm{s}) ;{ }^{13} \mathrm{C}-\mathrm{NMR}\left(\mathrm{CDCl}_{3}\right)$ : (excitation time: $0.004 \mathrm{~s}$; relaxation time: $\left.6 \mathrm{sec}\right) \delta 11.4^{*}, 12.3$ (for enriched methyl groups); MS (m/e, \%): 168 (69), 153 (71), 137 (100), 109 (26), 108 (30), $93(41), 68(36), 58(56)$, 57 (28), 56 (35), 53 (9), 42 (37); calculated exact mass for $\mathrm{C}_{8}{ }^{13} \mathrm{CH}_{13} \mathrm{NO}_{2}: 168.0980$, found: 168.0976. 
N-Benzyloxycarbonyl-2-13 C-alanine (1ha): To a solution of $2-13 \mathrm{C}$-alanine $(0.300 \mathrm{~g}, 3.33 \mathrm{mmol})$ in $4 \mathrm{M} \mathrm{NaOH}(0.850 \mathrm{~mL})$ was added, in five portions of $0.160 \mathrm{~mL}$ each, a total of $0.800 \mathrm{~mL}$ benzyl chloroformate $(0.850 \mathrm{~g}, 5.00 \mathrm{mmol})$ over a period of $1 \mathrm{hr}$. The reaction mixture was kept at $0^{\circ} \mathrm{C}$ throughout the addition period. An additional $0.200 \mathrm{~mL}$ portion of benzyl chloroformate was added at the end of the addition period, and the mixture was stirred at room temperature for 35 minutes. The $\mathrm{pH}$ of the aqueous mixture was adjusted to 10.0 with $2 \mathrm{~N} \mathrm{NaOH}$, and the mixture was washed once with ether to remove unreacted benzyl chloroformate. The aqueous layer was then acidified to $\mathrm{pH}<2.0$ with $3 \mathrm{M} \mathrm{HCl}$. The turbid solution was extracted with ethyl acetate $(3 \times 15 \mathrm{~mL})$. The combined organic layers were dried $\left(\mathrm{MgSO}_{4}\right)$, filtered, and solvents were removed in vacuo. The oily residue was crystallized from ethyl acetate/hexanes, to give $0.570 \mathrm{~g}$ (76.0\%) of 1ha as a colorless solid, m.p. $87-89^{\circ} \mathrm{C}$. IR (KBr): 3332 (vs), 3300-2500 (b), 1692 (vs), 1534 (s), $1292(\mathrm{~s}), 1253$ (s), $1072(\mathrm{~s}), 1026(\mathrm{~m}) \mathrm{cm}^{-1} ; 1 \mathrm{H}-\mathrm{NMR}$ (CDCl3): $87.32(5 \mathrm{H}, \mathrm{s}), 5.20$ (2H, bs), 4.43 $(1 \mathrm{H}, \mathrm{q}, \mathrm{J}=7.0 \mathrm{~Hz}), 1.49(3 \mathrm{H}, \mathrm{dd}, \mathrm{J}=130.0 \mathrm{~Hz}, 7.0 \mathrm{~Hz})$; MS (m/e, \%): $224(10), 135(10), 108(90), 91$ (100); calculated exact mass for $\mathrm{C}_{10}{ }^{13} \mathrm{CH}_{13} \mathrm{NO}_{4}$ : 224.0878 , found: 224.0871 .

N-Methyl-N-benzyloxycarbonyl-2-13 C-alanine (1hb): Compound 1 hb was prepared according to the general procedure of $\mathrm{McDermott}$ and Benoiton. 43 Thus, to a stirred $0^{\circ} \mathrm{C}$ solution of $1 \mathrm{ha}(0.490 \mathrm{~g}, 2.19$ $\mathrm{mmol}$ ) in THF (7 mL) was added iodomethane $(1.20 \mathrm{~mL}, 19.3 \mathrm{mmol})$. Sodium hydride $(0.450 \mathrm{~g}, 50 \%$ dispersion in mineral oil, $9.38 \mathrm{mmol}$, rinsed with dry pentane) was added slowly to the mixture. The mixture was stirred at room temperature for 24 hours. The mixture was diluted with ethyl acetate $(6 \mathrm{~mL})$, and water $(10$ $\mathrm{mL}$ ) was added to consume any remaining sodium hydride. The organic layer was separated, and the aqueous layer was extracted once with ether $(10 \mathrm{~mL})$ to remove any remaining iodomethane. The ether layer was separated and washed with saturated aqueous sodium bicarbonate. The combine aqueous layers were acidified to $\mathrm{pH}<2.0$ with $3.0 \mathrm{M} \mathrm{HCl}$. The mixture was extracted with ethyl acetate $(3 \times 15 \mathrm{~mL})$. The combined organic layers were washed once with $10 \mathrm{~mL}$ of $5 \%$ aqueous sodium thiosulfate and twice with $10 \mathrm{~mL}$ of water. The organic layer was then dried $\left(\mathrm{MgSO}_{4}\right)$ and filtered. Solvents were removed under reduced pressure giving the crudc product as a colorless oil $(0.507 \mathrm{~g}, 98 \%)$. The crude material was used in the subsequent hydrogenolysis step without further purification. IR (neat): 3611 - 2400 (b), 1742 (vs), 1704 (vs), 1680 (vs), 1455 (s), 1405 (s), 1320 (s), 1162 (s) cm-1; ${ }_{1} \mathrm{H}-\mathrm{NMR}$ (CDCl3, $300 \mathrm{MHz}$ ): 87.33 (bs, 5H), $5.16(\mathrm{~s}, 2 \mathrm{H}), 4.93,4.75$ (rolamer*, 40\%) (m, m*; 1H), 3.02 (bs, 3H), 1.48 (dd, J=128.9, 6.8 Hz, 3H); MS (m/e, \%): 238 (1), 193 (10), $149(15), 122(3), 108(12), 103(18), 91(100), 77$ (3), 65 (7), 59 (4), 51 (2), 42 (4); exact mass calculated for $\mathrm{C}_{11}{ }^{13} \mathrm{CH}_{15} \mathrm{NO}_{4}$ : 238.1035; found: 238.1033 .

N-Methyl-2.13 C-alanine (1hc): To a solution of $1 \mathrm{hb}(0.500 \mathrm{~g}, 2.10 \mathrm{mmol})$ in methanol $(10 \mathrm{~mL})$ was added glacial acetic acid $(1.0 \mathrm{~mL})$ and $10 \%$ palladium on activated carbon $(0.080 \mathrm{~g})$. The mixture was stirred 9 $\mathrm{hr}$ at room temperature under a positive atmosphere of hydrogen gas. The mixture was filtered, and the solids were rinsed with methanol. Methanol and acetic acid were removed in vacuo. The oily residue was crystallized from methanol/acetic acid/acetone, to give $0.132 \mathrm{~g}(61 \%)$ of a colorless solid. IR (KBr): $3500-2400$ (b). 1584

(vs), 1394 (s), 1351 (s) cm ${ }^{-1}$; ${ }^{1}$ H-NMR (D2O, $360 \mathrm{MHz}$ ): 83.48 (q, J=7 Hz, 1H), 2.55 (s, 3H), 1.35 (dd, J $=129,7 \mathrm{~Hz}, 3 \mathrm{H}) ; \mathrm{MS}(\mathrm{m} / \mathrm{e}, \%): 104$ (3), 87 (3), 59 (100), 57 (17), 45 (12), 42 (15); exact mass calculated for

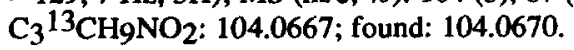

$\mathrm{N}$-Acetyl-N-methyl-2-13 C-alanine (1h): To a stirred, room temperature solution of $1 \mathrm{hc}(0.102 \mathrm{~g}$, $0.961 \mathrm{mmol})$ in $2 \mathrm{M} \mathrm{NaOH}(1.3 \mathrm{~mL})$ was added acetic anhydride $(0.292 \mathrm{~g}, 0.270 \mathrm{~mL}, 2.86 \mathrm{mmol})$. The mixture stirred at room temperature for 2.25 hours. After cooling the solution to $0^{\circ} \mathrm{C}$, the $\mathrm{pH}$ was adjusted to $<$ 2 with $3 \mathrm{M} \mathrm{HCl}$. The solution was extracted ethyl acetate $(3 \times 15 \mathrm{~mL})$, and the combined organic layers were dried (MgSO4) and filtered. Solvents were removed under reduced pressure, and the oily residue solidified on standing. The solid material was recrystallized from ethyl acetate/hexanes, giving $1 \mathrm{~h}(0.048 \mathrm{~g}, 33.5 \%)$ as a colorless solid, m.p. $92-94^{\circ} \mathrm{C}$. IR (KBr): $3400-2500$ (b). 1730 (vs), 1602 (vs). 1214 (s) cm-1; ${ }^{-1}$ H-NMR $\left(\mathrm{CDCl}_{3}, 360 \mathrm{MHz}\right.$, as rotamers, major:minor* ca. 6:1): $85.14,4.53^{*}\left(\mathrm{q}, \mathrm{J}=7 \mathrm{~Hz} ; \mathrm{q}^{*}, \mathrm{~J}=7 \mathrm{~Hz} ; 1 \mathrm{H}\right), 2.96$, $2.80^{*}\left(\mathrm{~s} ; \mathrm{s}^{*} ; 3 \mathrm{H}\right), 2.18(\mathrm{~s}, 3 \mathrm{H}), 1.43,1.51^{*}\left(\mathrm{dd}, \mathrm{J}=130,7 \mathrm{~Hz} ; \mathrm{dd}^{*}, \mathrm{~J}=130,7 \mathrm{~Hz} ; 3 \mathrm{H}\right) ; \mathrm{MS}(\mathrm{m} / \mathrm{e}, \%): 146$ (7), $101(43), 88(4), 86(0.3), 59(100), 57(15), 45(6), 43(29)$; exact mass calculated for $\mathrm{C}_{5}{ }^{13} \mathrm{CH}_{11} \mathrm{NO}_{3}$ : 146.0772; found: 146.0771 . 
Methyl 1,2-13 C,5-trimethylpyrrole-3-carboxylate (3h) and methyl 1,2,5-13 C-trimethylpyrrole-3-carboxylate (4h): To a stirred, room temperature solution of $1 \mathrm{~h}(0.043 \mathrm{~g}, 0.30 \mathrm{mmol})$ in acetic anhydride $(0.41 \mathrm{~mL})$ was added methyl propiolate $(0.074 \mathrm{~mL}, 0.070 \mathrm{~g}, 0.831 \mathrm{mmol})$. The mixture was heated to $65^{\circ} \mathrm{C}$ for $3 \mathrm{hr}$. Solvents and unreacted dipolarophile were removed in vacuo, to give the crude mixture of $3 \mathrm{~h}$ and $4 \mathrm{~h}$ as a colorless solid $(0.040 \mathrm{~g}, 80 \%)$. m.p. $115-117^{\circ} \mathrm{C}$. IR (KBr): 3448 (bs), 1686 (vs), 1638 (s), 1560 (s), 1534 (m), 1226 (s), 1069 (s) cm-1; ${ }^{1}$ H-NMR (CDCl3, 300 MHz): 3h, 4h*: 86.23 (s, 1H), 3.78 (s, 3H), $3.39(\mathrm{~s}, 3 \mathrm{H}), 2.50\left(\mathrm{~d}, \mathrm{~J}=126 \mathrm{~Hz} ; \mathrm{s}^{*} ; 3 \mathrm{H}\right), 2.18\left(\mathrm{~s} ; \mathrm{d}^{*}, \mathrm{~J}=126 \mathrm{~Hz} ; 3 \mathrm{H}\right)$, relative isomer ratio 3h:4h* = 47:53; ${ }^{13} \mathrm{C}$-NMR ( $\mathrm{CDCl} 3$ ): (excitation time: 0.004s; relaxation time: $6 \mathrm{sec}$ ): $811.4,12.3^{*}$ (for enriched methyl groups), relative isomer ratio 3h:4h = 47:53; MS (m/e): $168(100), 153(61), 137(72), 123(1), 108(17), 93$ (2), 80 (2), 68 (18), 57 (16), 52 (5), 42 (21); calculated exact mass for $\mathrm{Cg}_{8}{ }^{13} \mathrm{CH}_{13} \mathrm{NO}_{2}$ : 168.0980; found: 168.0976.

$\mathrm{N}$-Acetyl-N-methylalanine (1i): To a solution of $\mathrm{N}$-methylalanine $(1.51 \mathrm{~g}, 14.5 \mathrm{mmol})$ in $2 \mathrm{M} \mathrm{NaOH}(8.7$ $\mathrm{mL}$ ) was added acetic anhydride $(4.16 \mathrm{~mL}, 4.49 \mathrm{~g}, 44.0 \mathrm{mmol})$. The mixture was stirred at $50^{\circ} \mathrm{C}$ for $1.5 \mathrm{hr}$, after which time TLC showed no remaining $\mathrm{N}$-methylalanine $\left(60: 40 \mathrm{CH}_{3} \mathrm{CN} / \mathrm{NH} 4 \mathrm{OAc}\right.$, Ninhydrin, $\left.\mathrm{R}_{\mathrm{f}}=0.50\right)$. The mixture was cooled on an ice bath and acidified to $\mathrm{pH}<2$ with $6 \mathrm{~N} \mathrm{H}_{2} \mathrm{SO}_{4}$. The aqueous solution was extracted ethyl acetate $(3 \times 15 \mathrm{~mL})$. The combined organic layers were dried (MgSO4), filtered, and evaporated under reduced pressure. The oily residue was dried in vacuo, giving a colorless solid. The solid was recrystallized from ethyl acetate/hexanes giving $1.27 \mathrm{~g}(66 \%)$ of $1 \mathbf{i}$ as a colorless solid, m.p. $97-99^{\circ} \mathrm{C}$. IR (KBr): 3600 - 2200 (b), 1731 (vs), 1600 (vs), 1416 (s), 1214 (s) $\mathrm{cm}^{-1} ;{ }^{1} \mathrm{H}-\mathrm{NMR}\left(\mathrm{CDCl}_{3}, 300 \mathrm{MHz}\right): 85.15$ $(\mathrm{q}, \mathrm{J}=7.6 \mathrm{~Hz}, 1 \mathrm{H}), 2.93(\mathrm{~s}, 3 \mathrm{H}), 2.09(\mathrm{~s}, 3 \mathrm{H}), 1.30(\mathrm{~d}, \mathrm{~J}=7.6 \mathrm{~Hz}, 3 \mathrm{H}) ; \mathrm{MS}(\mathrm{m} / \mathrm{e}, \%): 145(8), 100(44)$, $88(0.2), 86(1), 58(100), 56(21), 43$ (29); calculated exact mass for $\mathrm{C}_{6} \mathrm{H}_{11} \mathrm{NO}_{3}$ : 145.0739; found: 145.0745 .

Methyl 1,2,5-trimethylpyrrole-3-carboxylate. (3i=4i): To a stirred, room temperature suspension of 1i $(0.050 \mathrm{~g}, 0.345 \mathrm{mmol})$ in acetic anhydride $(0.48 \mathrm{~mL}, 5.0 \mathrm{mmol})$ was added methyl propiolate $(0.086 \mathrm{~mL}$, $0.0813 \mathrm{~g}, 0.967 \mathrm{mmol}$ ). The mixture was stirred at $65^{\circ} \mathrm{C}$ for $2.5 \mathrm{hr}$. Solvents and excess dipolarophile were removed in vacuo to give the crude product as a brown solid. The material was purified by flash chromatography $\left(5: 1\right.$ hexane/ethyl acetate eluent, $\left.R_{f}=0.30\right)$, to give $0.033 \mathrm{~g}(62 \%)$ of $3 i=4 i$ as a colorless solid, m.p. 117-118 ${ }^{\circ} \mathrm{C}$. IR (KBr): 2900 (m), 1689 (vs), 1533 (s), 1439 (s), 1226 (vs), 1191 (s), 1070 (s) $\mathrm{cm}^{-1}$; ${ }^{1} \mathrm{H}-\mathrm{NMR}\left(\mathrm{CDCl}_{3}, 300 \mathrm{MHz}\right): \delta 6.23(\mathrm{~s}, 1 \mathrm{H}), 3.78(\mathrm{~s}, 3 \mathrm{H}), 3.39(\mathrm{~s}, 3 \mathrm{H}), 2.50(\mathrm{~s}, 3 \mathrm{H}), 2.18(\mathrm{~s}, 3 \mathrm{H})$. MS (m/e, \%): 167 (100), 152 (63), $136(73), 107$ (17), 92 (2), 79 (2), 67 (25), 56 (30), 52 (5), 42 (20); calculated exact mass for $\mathrm{C}_{9} \mathrm{H}_{13} \mathrm{NO}_{2}$ : 167.0946; found: 167.0939 .

Methyl 1,4- and 1,3-dimethyl-2-phenylthio-3- and 4-pyrrolecarboxylate (Table IV, entry 2): Reaction of $1 \mathrm{~d}(345 \mathrm{mg}, 1.5 \mathrm{mmol})$ with methyl 2-butynoatc $(150 \mathrm{mg}, 1.5 \mathrm{mmol})$ under the cycloaddition conditions gave $360 \mathrm{mg}(90 \%)$ of the title compounds as inseparable oils. IR (CDCl3): 1700, 1425, 1250, $1075 \mathrm{~cm}^{-1}$; ${ }^{1} \mathrm{H}-\mathrm{NMR}\left(3^{*}+4-\mathrm{isomer}, \mathrm{CDCl}_{3}\right): 82.27^{*}(3 \mathrm{H}, \mathrm{s}), 3.53^{*}(3 \mathrm{H}, \mathrm{s}), 3.76^{*}(3 \mathrm{H}, \mathrm{s}), 6.62^{*}(1 \mathrm{H}$, bs), 6.99-7.08*(5H, m); $2.38(3 \mathrm{H}, \mathrm{s}), 3.54(3 \mathrm{H}, \mathrm{s}), 3.8(3 \mathrm{H}, \mathrm{s}), 6.9-7.2(5 \mathrm{H}, \mathrm{m}), 7.47(\mathrm{HH}, \mathrm{s}) ; \mathrm{MS}(\mathrm{m} / \mathrm{e}$, $\%): 261$ (1), 246 (12), 230 (20), 203 (15), 152 (32); calculated exact mass for $\mathrm{C}_{14} \mathrm{H}_{15} \mathrm{NO}_{2} \mathrm{~S}$ : 261.0820 ; found: 261.0836 .

Methyl 1-methyl-3-phenyl-2-phenylthio-4-pyrrolecarboxylate (Table IV, entry 3): Reaction of 1d $(297 \mathrm{mg}, 1.3 \mathrm{mmol})$ with methyl phenylpropiolate $(0.21 \mathrm{~g}, 1.3 \mathrm{mmol})$ under the cycloaddition conditions gave $400 \mathrm{mg}(94 \%)$ of a single regioisomer. The product was chromatographed (preparative TLC; 1:3 Et0Ac:hexane) to give $340 \mathrm{mg}$ (80\%) of the title compound, mp. 163-6 ${ }^{\circ} \mathrm{C}$; IR (CDC13): 2965, 1705, 1520, 1440, 1270, 1190, $1135 \mathrm{~cm}^{-1}$; ${ }_{\mathrm{H}-\mathrm{NMR}}\left(\mathrm{CDCl}_{3}\right): 83.47(3 \mathrm{H}, \mathrm{s}), 3.65(3 \mathrm{H}, \mathrm{s}), 6.87-7.27$ (10H, m), 7.53 $(1 \mathrm{H}, \mathrm{s}) ; \mathrm{MS}(\mathrm{m} / \mathrm{e}, \%)$ : $323(5), 308(20), 292(13), 277(18), 214$ (39), 199 (67), 184 (75); calculated exact mass for $\mathrm{C}_{19 \mathrm{H}_{1}} \mathrm{NO}_{2} \mathrm{~S}: 323.0976$; found: 323.0981 . 
$\mathrm{N}$-Formyl-N-methylvaline (Table VI, entry 1): To a stirred, $0^{\circ} \mathrm{C}$ solution of $\mathrm{N}$-methylvaline $(0.090 \mathrm{~g}$, $0.689 \mathrm{mmol})$ in $88 \%$ aqueous formic acid $(0.770 \mathrm{~mL})$ was added, dropwise, acetic anhydride $(0.447 \mathrm{~mL}$, $0.482 \mathrm{~g}, 4.72 \mathrm{mmol}$ ). The solution was stirred at room temperature for $3 \mathrm{hr}$. The mixture was dried in vacuo 9 hours to give the title compound as a clear, colorless oil $(0.097 \mathrm{~g}, 88 \%)$. The material was sufficiently pure for characterization and was used without further purification. IR (neat): $2800-3500$ (b), 1732 (vs), 1637 (vs), 1471 (s), 1391 (vs), 1276 (s), 1255 (s), 1250 (s), 1210 (vs), 1067 (s) cm-1 ; ${ }^{-1}$-NMR (CDCl3, $360 \mathrm{MHz}$, as rotamers in a ca. $3: 2^{*}$ ratio): $88.11^{*}, 8.10\left(\mathrm{~s}^{*} ; \mathrm{s} ; 1 \mathrm{H}\right), 4.60^{*}, 3.61 \mathrm{ppm}\left(\mathrm{d}^{*}, \mathrm{~J}=7 \mathrm{~Hz} ; \mathrm{d}, \mathrm{J}=7 \mathrm{~Hz} ; 1 \mathrm{H}\right), 3.05^{*}$, $2.90(\mathrm{~s}, 3 \mathrm{H}), 2.30(\mathrm{bm}, 1 \mathrm{H}), 1.09(\mathrm{~m}, 3 \mathrm{H}), 0.90(\mathrm{~m}, 3 \mathrm{H}) ; \mathrm{MS}(\mathrm{m} / \mathrm{e}, \%): 159(8), 114(96), 99(42), 88(41)$, $86(53), 70$ (27), 60 (33), $55(39), 42$ (100), 39 (32); calculated exact mass for $\mathrm{C}_{7} \mathrm{H}_{13} \mathrm{NO}_{3}$ : 159.0895; found: 159.0890 .

Methyl 2-isopropyl-1-methylpyrrole-3-carboxylate (A) and Methyl 5-isopropyl-1-methylpyrrole-3-carboxylate (B) (Table VI, entry 1): To a stirred suspension of $\mathrm{N}$-formyl-N-methylvaline $(0.072 \mathrm{~g}, 0.453 \mathrm{mmol})$ in dry acetic anhydride $(0.770 \mathrm{~mL}, 0.831 \mathrm{~g}, 8.15 \mathrm{mmol})$ was added methyl propiolate $(0.200 \mathrm{~mL}, 0.190 \mathrm{~g}, 2.26 \mathrm{mmol})$. The mixture was stirred for $2.5 \mathrm{hr}$ at $65^{\circ} \mathrm{C}$, after which point TLC indicated complete reaction $\left(2: 1\right.$ hexanes/ethyl acetate, $\left.R_{f} A / B=0.70\right)$. Solvents and unreacted dipolarophile were removed in vacuo, to give the crude products as a tan oil $(0.046 \mathrm{~g}, 56 \%)$. Ratio of regioisomers determined from crude and chromatographed reaction mixture, $A: B=57: 43$. The mixture was purified using column chromatography (silica gel, 2:1 hexanes/ethyl acetate, $R_{f}=0.70$ ). IR (neat): 2964 (vs), 1713 (vs), 1701 (vs), 1524 (s), 1507 (s), 1467 (s), 1457 (s), 1441 (s), 1250 (vs), 1200 (vs), 1173 (s) cm-1; ${ }_{1}^{1}$ H-NMR (CDCl3, 300 MHz): A: $\delta 6.48(\mathrm{~d}, \mathrm{~J}=3 \mathrm{~Hz}, 1 \mathrm{H}), 6.38(\mathrm{~d}, \mathrm{~J}=3 \mathrm{~Hz}, 1 \mathrm{H}), 3.87$ (q, J=7 Hz, 1H), $3.78(\mathrm{~s}, 3 \mathrm{H}), 3.61$ (s, 3H), $1.38) \mathrm{d}, \mathrm{J}=7 \mathrm{~Hz}, 6 \mathrm{H}) . \mathrm{B}: \delta 7.18(\mathrm{~m}, 1 \mathrm{H}), 6.31(\mathrm{~m}, 1 \mathrm{H}), 3.78(\mathrm{~s}, 3 \mathrm{H}), 3.57(\mathrm{~s}, 3 \mathrm{H}), 2.86(\mathrm{~g}, \mathrm{~J}=7 \mathrm{~Hz}, 1 \mathrm{H})$, 1.22 (d, J=7 Hz, 6H); MS (m/e, \%): 181 (47), 166 (100), 150 (28), 134 (44), 122 (11), 107 (31), 92 (5), 77 (10), $65(11), 59(5), 51(8), 42(20), 39(19)$; calculated exact mass for $\mathrm{C}_{10} \mathrm{H}_{15} \mathrm{NO}_{2}$ : 181.1102 ; found: 181.1103.

$\mathrm{N}$-Isobutyryl-N-methylglycine (Table VI, entry 2): To a stirred, $0^{\circ} \mathrm{C}$ solution of $\mathrm{N}$-methylglycine $(0.891 \mathrm{~g}, 10.0 \mathrm{mmol})$ in $2 \mathrm{M} \mathrm{NaOH}(5.00 \mathrm{~mL})$ was added, simultaneously, in five equal portions over 30 minutes, isobutyric anhydride $(1.70 \mathrm{~mL}, 1.62 \mathrm{~g}, 10.26 \mathrm{mmol})$ and diisopropylethylamine $(1.79 \mathrm{~mL}, 1.33 \mathrm{~g}$, $10.26 \mathrm{mmol}$ ). The solution was warmed to $40^{\circ} \mathrm{C}$ for $3 \mathrm{hr}$. The mixture was then cooled on an ice bath, and the $\mathrm{pH}$ was brought to $<2.0$ with $6 \mathrm{~N} \mathrm{H}_{2} \mathrm{SO}_{4}$. The aqueous solution was extracted ethyl acetate $(3 \times 15 \mathrm{~mL})$. The combined organic layers were dried $\left(\mathrm{MgSO}_{4}\right)$, filtered, and evaporated under reduced pressure. The oily residue was dried in vacuo, and excess isobutyric acid was removed by azeotropic distillation in vacuo with toluene. The solid residue was recrystallized from hot ethyl acetate/hexanes, giving the product as a colorless solid (1.29g, 81\%). m.p. $108-109^{\circ} \mathrm{C}$. IR (KBr): 3000-2800 (b), 1758 (vs), 1736 (vs), 1609 (vs), 1500 (vs), 1425 (vs), 1408 (vs), 1211 (vs), 1092 (vs) cm ${ }^{-1}$; ${ }^{1} \mathrm{H}-\mathrm{NMR}$ ( $\mathrm{CDCl}_{3}, 300 \mathrm{MHz}$, as rotamers in a ca. 3:2* ratio): $\delta 9.10(\mathrm{~b}, 1 \mathrm{H}), 4.14,4.10^{*}\left(\mathrm{~s} ; \mathrm{s}^{*} ; 2 \mathrm{H}\right), 3.13,2.98^{*}$ (s; $\left.\mathrm{s}^{*} ; 3 \mathrm{H}\right), 2.87,2.65^{*}$ (q, J=7.6 Hz; $\mathrm{q}^{*}$, $\mathrm{J}=7.6 \mathrm{~Hz} ; 1 \mathrm{H}), 1.18,1.15^{*}\left(\mathrm{~d}, \mathrm{~J}=7.6 \mathrm{~Hz} ; \mathrm{d}^{*}, \mathrm{~J}=7.6 \mathrm{~Hz} ; 6 \mathrm{H}\right) ; \mathrm{MS}(\mathrm{m} / \mathrm{e}, \%): 159(15), 115(46), 100(10)$, 88 (34), 71 (51), 58 (6), 55 (11), 44 (100); calculated exact mass for $\mathrm{C}_{7} \mathrm{H}_{13} \mathrm{NO}_{3}$ : 159.0895; found: 159.0903 .

Methyl 5-isopropyl-1-methylpyrrole-3-carboxylate (A) and Methyl 2-isopropyl-1-methylpyrrole-3-carboxylate (B) (Table VI, entry 2): To a stirred, room temperature solution of $\mathrm{N}$ isobutyryl- $\mathrm{N}$-methylglycine $(0.200 \mathrm{~g}, 1.26 \mathrm{mmol})$ in dry acetic anhydride $(2.13 \mathrm{~mL}, 2.30 \mathrm{~g}, 22.6 \mathrm{mmol})$ was added methyl propiolate $(0.560 \mathrm{~mL}, 0.529 \mathrm{~g}, 6.29 \mathrm{mmole})$. The mixture was stirred for $2.5 \mathrm{hr}$ at $60^{\circ} \mathrm{C}$. TLC indicated a complete reaction after 2 hours $\left(2: 1\right.$ hexanes/ethyl acetate, $\left.R_{f} \mathbf{A} / \mathbf{B}=0.90\right)$. Solvents and excess dipolarophile were removed in vacuo, to give the crude products as a $\tan$ oil $(0.210 \mathrm{~g}, 92 \%)$. Ratio of regioisomers determined from crude and chromatographed reaction mixture, $\mathbf{A}: \mathbf{B}=75: 25$. A portion of the crude material was purified by column chromatography $(2: 1$ hexanes/ethyl acetate, $R f=0.90)$, to give a light yellow oil. IR (neat): 2969 (vs), 1731 (vs), 1703 (vs), 1648 (vs), 1250 (s), 1202 (s), 1188 (s), 1174 (s) $\mathrm{cm}^{-1}$; ${ }^{1} \mathrm{H}-\mathrm{NMR}\left(\mathrm{CDCl}_{3}, 300 \mathrm{MHz}\right): \mathrm{A}: 86.48(\mathrm{~d}, \mathrm{~J}=3 \mathrm{~Hz}, 1 \mathrm{H}), 6.38(\mathrm{~d}, \mathrm{~J}=3 \mathrm{~Hz}, 1 \mathrm{H}), 3.87$ (q, J=7 Hz, $1 \mathrm{H}), 3.78(\mathrm{~s}, 3 \mathrm{H}), 3.61(\mathrm{~s}, 3 \mathrm{H}), 1.38(\mathrm{~d}, \mathrm{~J}=7 \mathrm{~Hz}, 6 \mathrm{H}) ; \mathbf{B}: 87.18(\mathrm{~m}, 1 \mathrm{H}), 6.31(\mathrm{~m}, 1 \mathrm{H}), 3.78(\mathrm{~s}, 3 \mathrm{H}), 3.57$ $(\mathrm{s}, 3 \mathrm{H}), 2.86(\mathrm{q}, \mathrm{J}=7 \mathrm{~Hz}, 1 \mathrm{H}), 1.22(\mathrm{~d}, \mathrm{~J}=7 \mathrm{~Hz}, 6 \mathrm{H}) ; \mathrm{MS}(\mathrm{m} / \mathrm{e}, \%): 181$ (47), 166 (100), 150 (28), 134 (44), 122 (11), 107 (31), 92 (5), 77 (10), 65 (11), 59 (5), 51 (8), 42 (20), 39 (19); calculated exact mass for $\mathrm{C}_{10} \mathrm{H}_{15} \mathrm{NO}_{2}$ : 181.1102 ; found: 181.1107 . 
$\mathrm{N}$-Isobutyryl-N-methylalanine (Table VI, entry 3): To a stirred, $0^{\circ} \mathrm{C}$ solution of $\mathrm{N}$-methylalanine $(0.500 \mathrm{~g}, 4.80 \mathrm{mmol})$ in $2 \mathrm{M} \mathrm{NaOH}(2.40 \mathrm{~mL})$ was added, simultaneously, in five equal portions spaced 6 minutes apart, diisopropylethylamine $(0.637 \mathrm{~g}, 0.860 \mathrm{~mL}, 4.93 \mathrm{mmol})$ and isobutyric anhydride $(0.780 \mathrm{~g}$, $0.818 \mathrm{~mL}, 4.93 \mathrm{mmol}$ ). The solution was heated to $40^{\circ} \mathrm{C}$ for $3.5 \mathrm{hr}$. The mixture was cooled to $0^{\circ} \mathrm{C}$, and acidified to $\mathrm{pH}<2.0$ with $6 \mathrm{~N} \mathrm{H}_{2} \mathrm{SO}_{4}$. The aqueous mixture was extracted with ethyl acetate $(3 \times 15 \mathrm{~mL})$. The combined organic layers were dried $\left(\mathrm{MgSO}_{4}\right)$, filtered, and evaporated under reduced pressure. The oily residue was dried in vacuo, and isobutyric acid was removed by azeotropic distillation in vacuo with toluene. The residue was crystallized from toluene/hexanes as a light yellow solid and then recrystallized from ethyl acetate/hexanes as a colorless solid $\left(0.137 \mathrm{~g}, 17 \%\right.$ ), m.p. 84-86 ${ }^{\circ} \mathrm{C}$. IR (KBr): 2975 (vs), 2941 (vs), 2882 (s), 1734 (vs), 1608 (vs), 1602 (vs), 1486 (s), 1419 (s), 1307 (s), 1205 (vs), 1180 (s), 1098 (s) cm-1; ${ }^{\text {H }-N M R ~}$ $\left(\mathrm{CDCl}_{3}, 360 \mathrm{MHz}\right.$, as rotamers in a ca. $6: 1^{*}$ ratio): $85.17,4.60^{*}\left(\mathrm{q}, \mathrm{J}=7.3 \mathrm{~Hz} ; \mathrm{q}^{*}, \mathrm{~J}=7.3 \mathrm{~Hz} ; 1 \mathrm{H}\right), 3.00$, $2.82^{*}\left(\mathrm{~s} ; \mathrm{s}^{*} ; 3 \mathrm{H}\right), 2.83(\mathrm{~m}, 1 \mathrm{H}), 1.50^{*}, 1.48\left(\mathrm{~d}^{*}, \mathrm{~J}=7.3 \mathrm{~Hz} ; \mathrm{d}, \mathrm{J}=7.3 ; 3 \mathrm{H}\right), 1.13(\mathrm{~d}, \mathrm{~J}=7 \mathrm{~Hz}, 6 \mathrm{H}) ; \mathrm{MS}$ $(\mathrm{m} / \mathrm{e}, \%): 173(3), 129(20), 114(7), 102(18), 86(6), 71(15), 58(100), 43$ (53); calculated exact mass for $\mathrm{C}_{8} \mathrm{H}_{15} \mathrm{NO}_{3}$ : 173.1052; found: 173.1051 .

Methyl 5-isopropyl-1,2-dimethylpyrrole-3-carboxylate (A) and methyl 2-isopropyl-1,5dimethylpyrrole-3-carboxylate (B) (Table VI, entry 3): To a suspension of $\mathrm{N}$-isobutyryl-Nmethylalanine $(0.050 \mathrm{~g}, 0.29 \mathrm{mmol})$ in acetic anhydride $(0.490 \mathrm{~mL}, 5.20 \mathrm{mmol})$ was added methyl propiolate $(0.122 \mathrm{~g}, 1.45 \mathrm{mmol})$. The mixture was stirred at $65^{\circ} \mathrm{C}$ for $2.5 \mathrm{hr}$. Solvents and unreacted dipolarophile were removed in vacuo to give $0.050 \mathrm{~g}(88 \%)$.of the products as a light yellow oil sufficiently pure for characterization. Ratio of regioisomers determined from the reaction mixture, $\mathbf{A}: B=67: 33$. IR (neat): 2964 (vs), 1700 (vs), 1527 (vs), 1460 (s), 1438 (s), 1222 (vs), 1185 (s), 1062 (s), 775 (s) cm-1; ${ }^{1} \mathrm{H}-\mathrm{NMR}$ $\left(\mathrm{CDCl}_{3}, 300 \mathrm{MHz}\right): \mathrm{A}: 86.25$ (d, J = 1.0 Hz, 1H), $3.79(\mathrm{~s}, 3 \mathrm{H}), 3.42(\mathrm{~s}, 3 \mathrm{H}), 2.85(\mathrm{~m}, 1 \mathrm{H}), 2.51$ (s, 3H), 1.21 (d, J = 7.27 Hz, 6H); B: $\delta 6.21(\mathrm{bq}, \mathrm{J}=1 \mathrm{~Hz}, 1 \mathrm{H}), 3.94(\mathrm{~m}, 1 \mathrm{H}), 3.75$ (s, 3H), 3.49 (s, 3H), 2.15 (bs, 3H), 1.40 (d, J = 7.27 Hz, 6H); MS (m/e, \%): 195 (48), $180(100), 164$ (16), 148 (15), 136 (3), 121 (10), 84 (1), 58 (10), 42 (10); calculated exact mass for $\mathrm{C}_{11} \mathrm{H}_{17} \mathrm{NO}_{2}$ : 195.1259; found: 195.1260.

Methyl 5-isopropyl-1,2-dimethylpyrrole-3-carboxylate (A) and methyl 2-isopropyl-1,5dimethylpyrrole-3-carboxylate (B) (Table VI, entry 4): To a solution of $\mathrm{N}$-methyl-N-acetylvaline $(0.100 \mathrm{~g}, 0.578 \mathrm{mmol})$ in dry acetic anhydride $(1.00 \mathrm{~mL}, 1.08 \mathrm{~g}, 10.4 \mathrm{mmol})$ was added methyl propiolate $(0.257 \mathrm{~mL}, 0.243 \mathrm{~g}, 2.88 \mathrm{mmol})$. The mixture was stirred at $60^{\circ} \mathrm{C}$ for $2.5 \mathrm{hr}$. Solvents and unreacted dipolarophile were removed in vacuo to give the crude products as a red oil. Ratio of regioisomers determined from the crude and chromatographed reaction mixture, $\mathbf{A}: \mathbf{B}=77: 23$. The crude product was purified by column chromatography (silica gel, $2: 1$ hexanes/ethyl acetate, $\operatorname{Rf}_{f} \mathbf{A} / \mathbf{B}=0.65$ ), to give the $0.095 \mathrm{~g}(84 \%)$ of the products as a light yellow oil. IR (neat): 2965 (vs), 1702 (vs), 1694 (vs), 1527 (vs), 1460 (vs), 1438 (s), 1414 (s), 1230 (vs), 1198 (s), 1185 (vs), 1171 (vs), 1061 (s), 774 (s) cm-1; ${ }_{1} \mathrm{H}-\mathrm{NMR}$ (CDCl3, $300 \mathrm{MHz}$ ): A: $86.25(\mathrm{~d}, \mathrm{~J}=1.0 \mathrm{~Hz}, 1 \mathrm{H}), 3.79(\mathrm{~s}, 3 \mathrm{H}), 3.42(\mathrm{~s}, 3 \mathrm{H}), 2.85(\mathrm{~m}, 1 \mathrm{H}), 2.51(\mathrm{~s}, 3 \mathrm{H}), 1.21(\mathrm{~d}, \mathrm{~J}=7.27 \mathrm{~Hz}$, 6H); B: $\delta 6.21$ (bq, J = 1 Hz, 1H), $3.94(\mathrm{~m}, 1 \mathrm{H}), 3.75(\mathrm{~s}, 3 \mathrm{H}), 3.49(\mathrm{~s}, 3 \mathrm{H}), 2.15(\mathrm{bs}, 3 \mathrm{H}), 1.40$ (d, J = $7.27 \mathrm{~Hz}, 6 \mathrm{H})$; MS (m/e, \%): 195 (46), $180(100), 164$ (16), $148(22), 136(3), 121$ (9), 84 (6), $56(8), 49$ (12), 42 (11); calculated exact mass for $\mathrm{C}_{11} \mathrm{H}_{17} \mathrm{NO}_{2}$ : 195.1259 ; found: 195.1257 .

N-Propanoyl-N-methylalanine (Table VI, entry 5): To a stirred, room temperature solution of $\mathrm{N}$ methylalanine $(0.350 \mathrm{~g}, 3.40 \mathrm{mmol})$ in $2 \mathrm{M} \mathrm{NaOH}(5.0 \mathrm{~mL})$ was added propanoic anhydride $(1.106 \mathrm{~g}, 1.10 \mathrm{~mL}$, $8.50 \mathrm{mmol}$ ). The mixture was stirred for $3 \mathrm{hr}$ at room temperature. The solution was cooled to $0^{\circ} \mathrm{C}$ and acidified to $\mathrm{pH}<2.0$ with $6 \mathrm{~N} \mathrm{H}_{2} \mathrm{SO}_{4}$. The aqueous layer was extracted with ethyl acetate $(3 \times 15 \mathrm{~mL})$ and the combined organic layers were dried $\left(\mathrm{MgSO}_{4}\right)$, filtered, and evaporated. The residual oil crystallized from hot ethyl acetate/petroluem ether as a colorless solid $(0.270 \mathrm{~g}, 50 \%)$, m.p. $80-82^{\circ} \mathrm{C}$. IR (KBr): $3500-2100$ (b), 1750 (vs), 1620 (vs), 1430 (s), 1210 (s) cm $\mathrm{cm}^{-1}$; ${ }_{\mathrm{H}-\mathrm{NMR}}\left(\mathrm{CDCl}_{3}, 360 \mathrm{MHz}\right): 5.17$ (q, J=6.7 Hz, 1H), 2.93 $(\mathrm{s}, 3 \mathrm{H}), 2.38(\mathrm{q}, \mathrm{J}=6.9 \mathrm{~Hz}, 2 \mathrm{H}), 1.42(\mathrm{~d}, \mathrm{~J}=6.7 \mathrm{~Hz}, 3 \mathrm{H}), 1.21(\mathrm{t}, \mathrm{J}=6.9 \mathrm{~Hz}, 3 \mathrm{H}) ; \mathrm{MS}(\mathrm{m} / \mathrm{e}, \%): 159(4)$, 115 (17), 114 (23), $102(9), 87$ (4), 58 (100), 42 (17); calculated exact mass for $\mathrm{C}_{7} \mathrm{H}_{13} \mathrm{NO}_{3}$ : 159.0895; found: 159.0885 . 
Methyl 2-ethyl-1,5-dimethylpyrrole-3-carboxylate (A) and methyl 5-ethyl-1,2-dimethylpyrrole-3-carboxylate (B) (Table VI, entry 5): To a stirred, room temperature solution of $\mathrm{N}$ propanonyl- $\mathrm{N}$-methylalanine $(0.122 \mathrm{~g}, 0.772 \mathrm{mmol})$ in dry acetic anhydride $(1.38 \mathrm{~mL})$ was added methyl propiolate $(0.232 \mathrm{~g}, 2.76 \mathrm{mmol}, 0.246 \mathrm{~mL})$. The mixture was stirred for $2.5 \mathrm{hr}$ at $65^{\circ} \mathrm{C}$. The mixture was cooled to room temperature.. Solvents and unreacted dipolarophile were removed in vacuo, to give the crude product as a red oil ( $83 \mathrm{mg}, 64 \%)$. Ratio of regioisomers determined from the crude and chromatographed reaction mixture, $\mathbf{A}: \mathbf{B}=45: 55$. The crude product was purified by column chromatography (silica gel, $2: 1$ hexanes/ethyl acetate, $\operatorname{Rf} \mathbf{A} / \mathbf{B}=0.75$ ) to give a colorless oil. IR (neat): 2950 (vs), 1750 (vs), 1700 (vs), 1650 (vs), 1575 (s), 1530 (vs), 1450 (vs), 1410 (vs), 1360 (vs), 1225 (vs), 1180 (vs), 1075 (vs), 1010 (vs), 775 (s) $\mathrm{cm}^{-1}$; ${ }^{1}$ H-NMR (CDCl3, $300 \mathrm{MHz}$ ): A: 86.25 (bs, 1H), 3.77 (s, 3H), 3.42 (s, 3H), 2.98 (q, J=7 Hz, $2 \mathrm{H}), 2.19(\mathrm{~s}, 3 \mathrm{H}), 1.25(\mathrm{t}, \mathrm{J}=7 \mathrm{~Hz}, 3 \mathrm{H}) . \mathrm{B}: 86.26 \mathrm{~s}(1 \mathrm{H}), 3.78(\mathrm{~s}, 3 \mathrm{H}), 3.40(\mathrm{~s}, 3 \mathrm{H}), 2.51(\mathrm{q}, \mathrm{J}=7 \mathrm{~Hz}, 2 \mathrm{H})$, $2.50(\mathrm{~s}, 3 \mathrm{H}), 1.15(\mathrm{t}, \mathrm{J}=7 \mathrm{~Hz}, 3 \mathrm{H})$; MS (m/e, \%): 181 (50), $166(100), 122(16), 150(31), 134(18), 107$ (15), 92 (4), 77 (6); calculated exact mass for $\mathrm{C}_{10} \mathrm{H}_{15} \mathrm{NO}_{2}$ : 181.1102 ; found: 181.1108.

N-Formyl-N-methyl-3-methylvaline. (Table VI, entry 6)

To a stirred, $0^{\circ} \mathrm{C}$ solution of $\mathrm{N}$-methyl-3-methylvaline $44(0.100 \mathrm{~g}, 0.689 \mathrm{mmol})$ in $88 \%$ aqueous formic acid $(0.770 \mathrm{~mL})$ was added, dropwise, acetic anhydride $(0.447 \mathrm{~mL}, 0.482 \mathrm{~g}, 4.72 \mathrm{mmol})$. The mixture was stirred at room temperature for an additional $3 \mathrm{hr}$. Removal of solvents in vacuo gave the title compound as a clear oil $(0.110 \mathrm{~g}, 92 \%)$. IR (neat): 3319 (m), 2971 (s), 3600-2200 (b), 1722 (s), 1631 (vs), 1376 (m), 1235 (s), 1075 (m) $\mathrm{cm}^{-1}$; ${ }^{1} \mathrm{H}-\mathrm{NMR}\left(\mathrm{CDCl}_{3}, 360 \mathrm{MHz}\right.$, as a mixture of rotamers in a ca. $2: 1^{*}$ ratio): $88.11,7.98^{*}\left(\mathrm{~s} ; \mathrm{s}^{*}\right.$; 1H), 4.89*, 3.82 (s*;s; 1H), 3.12*, 2.97 (s*; s; 3H), 1.08, 1.06* (s; s*; 9H); MS (m/e,\%): (CI, NH4 $\left.4^{+}\right): \mathrm{M}^{+}$ $174(40) 117(48), 99(100), 85(15), 71(19), 57(95), 41(69)$; calculated exact mass for $\mathrm{C}_{8} \mathrm{H}_{15} \mathrm{NO}_{3} \mathrm{H}^{+}$: 174.1130; found: 174.1134 .

Methyl 2-t-butyl-1-methylpyrrole-3-carboxylate (A) and methyl 5-t-butyl-1-methylpyrrole3-carboxylate (B) (Table VI, entry 6): To a stirred solution of $0.100 \mathrm{~g}(0.578 \mathrm{mmol})$ of $\mathrm{N}$-formyl-Nmethyl-3-methylvaline in acetic anhydride $(1 \mathrm{~mL})$ was added methyl propiolate $(0.173 \mathrm{~g}, 0.183 \mathrm{~mL}, 2.06$ $\mathrm{mmol}$ ). The solution was stirred at $65^{\circ} \mathrm{C}$ for $2.5 \mathrm{hr}$. Evaporation of the solvents in vacuo gave the products as

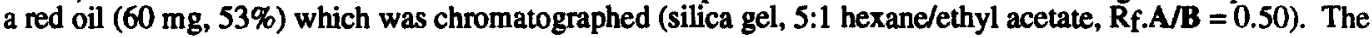
$A: B$ regioisomeric ratio, as determined from the crude and chromatographed reaction mixture, was 77:33. IR (neat): 2962 (vs), 1711 (vs), $1475(\mathrm{~m}), 1440(\mathrm{~m}), 1365$ (m), 1255 (s), 1220 (vs), 1204 (vs), 1158 (s) cm-1;

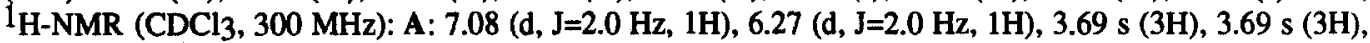
$1.43(\mathrm{~s}, 9 \mathrm{H}) ; \mathrm{B}: 6.28(\mathrm{~d}, \mathrm{~J}=3.15 \mathrm{~Hz}, 1 \mathrm{H}), 6.26(\mathrm{~d}, \mathrm{~J}=3.15 \mathrm{~Hz}, 1 \mathrm{H}), 3.69(\mathrm{~s}, 3 \mathrm{H}), 3.68(\mathrm{~s}, 3 \mathrm{H}), 1.26 \mathrm{~s}(9 \mathrm{H})$; MS (m/e, \%): 195 (40), 180 (100), 164 (19), $148(82), 121$ (14), 106 (6), 77 (8), 61 (16), 42 (22); calculated exact mass for $\mathrm{C}_{11} \mathrm{H}_{17} \mathrm{NO}_{2}$ : 195.1259 ; found: 195.1256 . 


\section{REFERENCES AND NOTES}

1. See, for example: a) Burdisso, M.; Gamba, A.; Gandolfi, R.; Toma, L.; Rastelli, A.; Schiatti, E. J. Org. Chem. 1990, 55, 3311-3321. b) Musicki, B. J. Org. Chem. 1990, 55, 910-918. c) Jones, R. C. F.; Nichols, J. R.; Cox, M. T. Tetrahedron Lett. 1990, 31, 2333-2336. d) Burdisso, M.; Gandolfi, R.; Grünanger, P.; Rastelli, A. J. Org. Chem. 1990, 55, 3427-3429. e) Fishwick, C. W. G.; Jones, A. D.; Mitchell, M. B.; Szantay, Jr., C. Tetrahedron Lett. 1988, 29, 5325-5328.

2. Creating regiochemical and stereochemical control elements for 1,3-dipolar cycloadditions has included hydrogen-bond steering, covalent and ionic intramolecular tethering, and chiral auxiliaries: a) Curran, D. P.; Choi, S.-M.; Gothe, S. A.; Lin, F. J. Org. Chem. 1990, 55, 3710-3712. b) Padwa, A. In 1,3Dipolar Cycloaddition Chemistry; Padwa, A., Ed.; Wiley: New York, 1984; Vol. 2, pp 277-406. c) Holmes, A. B.; Smith, A. L.; Williams, S. F.; Hughes, L. R.; Lidert, Z.; Swithenback, C. J. Org. Chem. 1991, 56, 1393-1405. d) Kanemasa, S.; Tsuruoka, T.; Wada, E. Tetrahedron Lett. 1993, 34, 87-90. e) Vedejs, E.; Piotrowski, D. W. J. Org. Chem. 1993, 58, 1341-1348. f) Henke, B. R.; Kouklis, A. J.; Heathcock, C. H. J. Org. Chem. 1992, 57, 7056-7066. g) Allway, P.; Grigg, R. Tetrahedron Lett. 1991, 32, 5817-5820. h) Harwood, L. M.; Lilley, I. A. Tetrahedron Lett. 1993, 34, 537-540. i) Curran, D. P.; Jeong, K.-S.; Heffner, T. A.; Rebek, Jr., J. J. Am. Chem. Soc. 1989, 111, 9238-9240. j) Garner, P.; Ho, W. B. J. Org. Chem. 1990, 55, 3973-3975. k) Kanemasa, S.; Yamamoto, H. Tetrahedron Lett. 1990 31, 3633-3636. 1) DeShong, P.; Li, W.; Kennington, Jr., J. W.; Ammon, H. L.; Leginus, J. M. J. Org. Chem. 1991, 56, 1364-1373. m) Akiyama, T.; Okada, K.; Ozaki, S. Tetrahedron Lett. 1992, 39, 5763-5766.

3. a) Sundaram, K.; Purcell, W. P. International Journal of Quantum Chemistry II 1968, 145-157. b) Houk, K. N.; and Yamaguchi, K. In 1,3-Dipolar Cycloaddition Chemistry; Padwa, A., Ed.; Wiley: New York, 1984; Vol. 2, pp 451-542. c) Fleming, I. Frontier Orbitals and Organic Chemical Reactions; Wiley: New York, 1976.

4. Huisgen, R. In Advances in Cycloaddition; Curran, D. P., Ed.; JAI Press: Greenwich, 1988; Vol. 1, pp 1-32.

5. Sustmann, R.; Sicking, W. Chem. Ber. 1987, 120, 1653-1658.

6. Sustmann, R.; Sicking, W.; Quast, H. J. Comp. Chem. 1992, 13, 314-317.

7. For example, a) Gingrich, H. L.; Baum, J. S. In Oxazoles; Turichi, I. J.. Ed.; Wiley: New York, 1986; Vol. 45 in the series The Chemistry of Heterocyclic Compounds; pp.731-961.b) Newton, C. G.; Ramsden, C. A. Tetrahedron 1982, 38, 2965-3011. b) Ollis, W. D.; Stanforth, S. P.; Ramsden, C. A. Tetrahedron 1985, 41, 2239-2329. c) Potts, K. T. In 1,3-Dipolar Cycloaddition Chemistry; Padwa, A., Ed.; Wiley: New York, 1984; Vol. 2, pp 1-82.

8. a) Huisgen, R.; Gotthardt, H.; Bayer, H. O. Chem. Ber. 1970, 103, 2368-2387. b) Knorr, R.; Huisgen, R. Chem. Ber. 1970, 103, 2598-2610. c) Huisgen, R.; Gotthardt, H.; Bayer, H. O.; Schaefer, F. C. Chem. Ber. 1970, 103, 2611-2624. d) Gotthardt, H.; Huisgen, R. Chem. Ber. 1970, 103, 2625-2638.

9. Padwa, A.; Burgess, E. M.; Gingrich, H. L.; Roush, D. M. J. Org. Chem. 1982, 47, 786-791. 
10. a) Dalla Croce, P.; La Rosa, C . Heterocycles 1988, 27, 2825-2832. b) Ibata, T.; Hamaguchi, M.; Kiyohara, H. Chem. Letters 1975, 21-24. c) Uchida, T.; Tsubokawa, S.; Harihara, K.; Matsumoto, K. J. Heterocyclic Chem. 1978, 15, 1303-1307. d) Clerici, F.; Erba, E.; Mornatti, P.; Trimarco, P. Chem. Ber. 1989, 122, 295-300. e) Dalla Croce, P.; Gariboldi, P.; La Rosa, C. J. Heterocyclic Chem. 1987, 24, 1793-1797. f) Texier, F.; Mazari, M.; Yebdri, O.; Tonnard, F.; Carrié, R. Bull. Soc. Chim. Fr. 1991, 128, 962-967.

11. a) Knorr, R.; Huisgen, R.; Staudinger, G. K. Chem. Ber. 1970, 103, 2639-2646. b) The intramolecular münchnone cycloadduct with olefinic dipolarophiles does not undergo cycloreversion equilibration under the cycloaddition conditions: Padwa, A.; Gingrich, H.; Lim, R. J. Org. Chem. 1982, 47, 2447-2456.

12. Toupet, P. L.; Mazari, M.; Texier, F.; Carrie, R. Acta Cryst. C 1991, 47, 1528-1531.

13. Intramolecular addition with olefinic dipolarophiles: a) Padwa, A.; Gingrich, H.; Lim, R. J. Org. Chem. 1982, 47, 2447-2456. b) Padwa, A.; Lim, R.; MacDonald, J. G.; Gingrich, H.; Kellar, S. M. J. Org. Chem. 1985, 50, 3816-3823. Intermolecular addition with olefinic dipolarophiles: See references 9d and 9e, and also: c) Texier, F.; Yebdri, O; Laidoudi, A; Tabli, B.; Balegroune, F.; Germain, G. Tetrahedron Lett. 1983, 24, 189-192. Intermolecular addition with acetylenic dipolarophiles: See references 9 and 10a, and also: d) Robins, D. J.; Sakdarat, S. J. Chem. Soc. Perkin Trans. I 1981, 909. 913. e) Potts, K. T.; Singh, U. P. J. Chem. Soc., Chem. Commun. 1969, 66.

14. a) Pizzorno, M. T.; Albonico, S. M. J. Org. Chem. 1977, 42, 909-910. b) Benages, I. A.; Albonico, S. E. J. Org. Chem. 1978, 43, 4273-4276.

15. Anderson, W. K.; Corey, P. F. J. Org. Chem. 1977, 42, 559-561.

16. a) Vedejs, E. In Advances in Cycloaddition; Curran, D. P., Ed.; JAI Press: Greenwich, 1988; Vol. 1, pp 33-52. b) Padwa has observed identical regioselectivities for the direct comparison between a münchnone and its unstabilized azomethine ylid counterpart bearing the same substituent pattern: Padwa, A.; Chen, Y.-Y.; Dent, W.; Nimmesgern, H. J. Org. Chem. 1985, 50, 4006-4014. c) Padwa, A.; Chen, Y.-Y.; Chiacchio, V.; Dent, W. Tetrahedron 1985, 41, 3529-3535. See also references Ic and $1 \mathrm{e}$.

17. a) Padwa, A.; Fryxell, G. E.; Zhi, L. J. Am. Chem. Soc. 1990, 112, 3100-3109. b) Padwa, A.; Chinn, R. L.; Hornbuckle, S. F.; Zhang, Z. J. J. Org. Chem. 1991, 56, 3271-3278.

18. Doyle, M. P.; Pieters, R. J.; Tauton, J.; Pho, H. Q.; Padwa, A.; Hertzog, D. L.; Precedo, L. J. Org. Chem. 1991, 56, 820-829.

19. See the comparison between entry $9 \mathbf{k}$ (Table I) and reference 16 in: Jungheim, L. N.; Sigmund, S. K. J. Org. Chem. 1987, 52, 4007-4013.

20. a) Trost, B. M.; Vladuchick, W. C.; Bridges, A. J. J. Am. Chem. Soc. 1980, 102, 3548-3554. b) Trost, B. M.; Vladuchick, W. C.; Bridges, A. J. J. Am. Chem. Soc. 1980, 102, 3554-3572; and references cited therein. c) Trost, B. M.; Matelich, M. C. J. Am. Chem. Soc. 1991, 113, 9007-9009.

21. a) N-Formyl-N-methylphenylalanine 1a was prepared according to: Quitt, P.; Hellerbach, J.; Vogler, K. Helv. Chim. Acta 1963, 46, 327-333. b) N-Methyl-N-(phenylacetyl)glycine $1 \mathrm{~b}$ was prepared according to: Kircheldorf, H. R. Chem. Ber. 1971, 104, 3156-3167.

22. N-Formyl- $\alpha$-arylthioamino acids were prepared according to the general method of amidoalkylation of thiols described in: Zoller, U.; Ben-Ishai, D. Tetrahedron 1975, 31, 863-866. 
23. a) The crude product material obtained after evaporation of solvents was subjected to regioisomeric analysis without further purification. Individual reactions were performed at least twice in order to make measurements of regioisomer ratios. Isomer ratios were obtained by two methods whenever possible: i) planimetric integration of analytical HPLC traces; and ii) planimetric integration of two separated methyl and/or methylene ${ }^{1} \mathrm{H}$-NMR singlets. The best 20 of 30 measurements were averaged. Standard deviations for isomer ratios were below $5 \%$ of the average (e.g.: $3.90 \pm 0.15: 1$ for 3c:4c represents $79.6 \pm 0.5 \%$ of $3 \mathrm{c}$ ). b) The ${ }^{1} \mathrm{H}-\mathrm{NMR}$ absorptions for pyrrole hydrogens, and their sensitivity to substituents, is well-known and allows for definitive regiochemical assignments, especially when both regioisomers are present. See: a) Pretsch, C.; Seibl, S. Spectral Data for Structure Determination of Organic Compounds, 2nd Ed.; Springer Verlag: Berlin, 1989, p. H295. b) Huisgen, R.; Gotthardt, H.; Weisshuhn, C. M.; Dorhofer, K. Chem. Ber. 1978, 111, 3336-3345., and references cited therein.

24. For a theoretical (FMO and reactivity modeling) treatment and tabulated experimental summaries of DielsAlder reaction regioselectivities based on diene substitutuents, see: Kahn, S. D.; Pau, C. F.; Overman, L. E.; Hehre, W. J. J. Am. Chem. Soc. 1986, 108, 7381-7396, and references cited therein.

25. a) Sustmann, R. Tetrahedron Lett. 1971, 2717-2420. b) Sustmann, R.; Trill, H. Angew. Chem. Int. Ed. Engl. 1972, 11, 838-840. c) Sustmann, R. Pure Appl. Chem. 1974, 40, 569-593. d) Huisgen, R. J. Org. Chem. 1976, 41, 403-419 . See also: references 9, 10, 11, 14, and 15.

26. MNDO calculations (Dewar, M. J. S.; Theil, W. J. Am. Chem. Soc. 1977, 99, 4907-4917.) were performed using the QPCE MOPAC program Version 5.0. Structure geometries were optimized with Sybyl Version 5.3 (Tripos Association, St. Louis, MO).

27. a) Houk, K. N.; Sims, J.; Duke, Jr., R. E.; Strozier, R. W.; George, J. K. J. Am. Chem. Soc. 1973, 95, 7287-7301. b) Houk, K. N.; Sims, J.; Watts, C. R.; Luskus, L. J. J. Am. Chem. Soc. 1973, 95 , 7301-7315.

28. A concerted yet asynchronous transition state for nitrile oxide/olefin cycloaddition reactions has been proposed: a) Houk, K. N.; Firestone, R. A.; Munchausen, L. L.; Mueller, P. H.; Arison, B. H.; Garcia, L. A. J. Am. Chem. Soc. 1985, 107, 7227-7228. The so-called limiting cases for stepwise bond formations have also been proposed. Both diradical and zwitterionic intermediates have been implicated to rationalize observed products. Diradical: b) Howe, R. K.; Shelton, B. R. J. Org. Chem. 1990, 55, 4603-4607. Zwitterionic: c) Huisgen, R.; Langhals, E. J. Org. Chem. 1990, 55, 1412-1414. d) Huisgen, R.; Mloston, G. Heterocycles 1990, 30, 737-740. e) Quast, H.; Regnat, D.; Peters, E.-M.; Peters, K.; von Schnering, H. G. Angew. Chem. Int. Ed. Eng. 1990, 29, 695-697. For general discussions about 1,3-dipolar transition state structures, see: f) Sustmann, R.; Sicking, W. Tetrahedron 1988, 44, 379-387. g) Dewar, M. J. S.; Hwang, J. C.; Kuhn, D. R. J. Am. Chem. Soc. 1991, 113, 735-741. h) Leroy, G.; Sana, M. Tetrahedron 1976, 32, 709-717. See also discussions in references 5 and $3 \mathrm{~b}$. i) For a discussion of unsymmetrical transition states and computational models, see: Sustmann, R.; Sicking, W.; Lamy-Schelkens, H.; Ghosez, L. Tetrahedron Lett. 1991, 32, 1401-1404.

29. Reported R1vs. R2 alkyl/alkyl münchnone substituents are a) methyl vs a tethered butyl : reference 14a. b) methyl vs a tethered propyl (and butyl): reference 14b. c) methyl vs benzyl: ref. 9 . d) methyl vs benzyl: reference $13 \mathrm{c}$.

30. For a notable exception, see reference 10c. 
31. Our initial experiments to prepare the $\mathbf{R}_{1} / \mathbf{R}_{2}=\mathrm{H} / \mathrm{D}$ and $\mathbf{R}_{1} / \mathbf{R}_{2}=\mathrm{CH}_{3} / \mathrm{CD}_{3}$ series of compounds were unsuccessful due to $H / D$ exchange reactions under any cycloaddition conditions.

32. The reported yields in this Scheme are for isolated, recrystallized materials and are not optimized.

33. a) Wolfram, M. L.; Lemieux, R. V.; Olin, S. M. J. Am. Chem. Soc. 1949, 71, 2870-2873. b) Chung, S. T. ; Benoitin, N. L. Can. J. Chem. 1977, 55, 916-921. c) Coggins, J. R.; Benoitin, N. L. Can. J. Chem. 1971, 49, 1968-1971.

34. Individual reactions were performed twice in order to make measurements of regioisomer ratios. Isomer ratios were obtained from averaging the NMR integrations of expanded spectral regions for three sets of peaks: ${ }^{1} \mathrm{H} \mathrm{C}-2 \mathrm{CH}_{3}{ }^{13} \mathrm{CH}_{3} ;{ }^{1} \mathrm{H} \mathrm{C}-4 \mathrm{CH}_{3}{ }^{13} \mathrm{CH}_{3} ;{ }^{13} \mathrm{C} \mathrm{C}-2 / \mathrm{C}-4$. The isomer ratio numbers all agreed to within $1-2 \%$.

35. The cycloaddition reactions of an intriguing bicyclic mesoionic compound with methyl propiolatc and methyl phenylpropiolate have been reported: see reference $1 \mathrm{~b}$. The pyrroles observed from reactions with both of these two dipolarophiles show the opposite type of substitution pattern as that found in entries 2 and 3 of Table $\mathbf{V}$. This is proposed to be due to a reversable cycloaddition reaction of this particular masked azomethine ylid that can achieve a thermodynamic distribution of the intermediate structures leading to the observed products. Methyl phenylpropiolate was also the dipolarophile used with a pair of regioisomeric münchnones that gave completely regioselctive formation of pyrroles that were insensitive to a set of aryl substituents (see ref. 10f).

36. March, J. Advanced Organic Chemistry, 4th Ed.; Wiley: New York, 1992; p. 215.

37. The amino acid derivatives were prepared according to literature precedents or authenic procedures: Chen, F. M. F.; Benoitin, N. L. Can. J. Chem. 1987, 65, 1224-1227; in addition to those in reference 29.

38. Coppola, B. P.; Noe, M. C.; Abdon, R. L. II ; Konsler, R. G. "A New Observation of Limiting Case 1,3-Dipolar Cycloaddition," submitted for publication. In a noteworthy example from this investigation, the picture of an unsymmetrical transition state with a high Michael-like character is strongly supported by a case where the major product is observed to be from a stepwise process initiated by a conjugate addition to the methyl propiolate.

39. Baker, J. J. Comp. Chem. 1986, 7, 385-395. Because of our initial positve results with this system, we are now pursuing other higher level computational methods to investigate our transition state structural hypothesis.

40. Reference 3b, p. 447.

41. Patel, R.; Price, S. J. Org. Chem. 1965, 30, 3575-3576.

42. Bonner, W. A.; McNamee, P. I. J. Org. Chem. 1961, 26, 2554-2555.

43. Methylation of N-benzyloxycarbonylamino acids: McDermott, J. R.; Benoiton, N. L. Can. J. Chem. 1973, 51, 1915-1919.

44. a) 3-Methylvaline: Miyazawa, T.; Takashima, K.; Mitsuda, Y.; Yamada, T.; Kuwata, S.; Watanabe, H. Bull. Chem. Soc. Japan 1979, 52, 1539-1540. b) Methylation of N-benzyloxycarbonyl derivative and subsequent hydrogenolysis performed as for compound thb (ref. 43) to give $\mathrm{N}$-methyl-3-methylvaline.

(Received in USA 16 August 1993; accepted 7 October 1993) 